\title{
Characterizing Spatial Neighborhoods of Refugia Following Large Fires in Northern New Mexico USA
}

\author{
Sandra L. Haire ${ }^{1, *}$, Jonathan D. Coop ${ }^{2}$ and Carol Miller ${ }^{3}$ \\ 1 Haire Laboratory for Landscape Ecology, Rockport, MA 01966, USA \\ 2 Center for Environment and Sustainability, Western State Colorado University, Gunnison, CO 81231, USA; \\ jcoop@western.edu \\ 3 Aldo Leopold Wilderness Research Institute, USDA Forest Service, Missoula, MT 59801, USA; \\ cmiller04@fs.fed.us \\ * Correspondence: sandra.louise.haire@gmail.com; Tel.: +1-413-362-4500
}

Academic Editors: Alistair M. S. Smith, James Lutz, Chad Hoffman, Grant Williamson and Andrew Hudak Received: 14 November 2016; Accepted: 28 February 2017; Published: 7 March 2017

\begin{abstract}
The spatial patterns resulting from large fires include refugial habitats that support surviving legacies and promote ecosystem recovery. To better understand the diverse ecological functions of refugia on burn mosaics, we used remotely sensed data to quantify neighborhood patterns of areas relatively unchanged following the 2011 Las Conchas fire. Spatial patterns of refugia measured within 10-ha moving windows varied across a gradient from areas of high density, clustered in space, to sparsely populated neighborhoods that occurred in the background matrix. The scaling of these patterns was related to the underlying structure of topography measured by slope, aspect and potential soil wetness, and spatially varying climate. Using a nonmetric multidimensional scaling analysis of species cover data collected post-Las Conchas, we found that trees and forest associates were present across the refugial gradient, but communities also exhibited a range of species compositions and potential functions. Spatial patterns of refugia quantified for three previous burns (La Mesa 1977, Dome 1996, Cerro Grande 2000) were dynamic between fire events, but most refugia persisted through at least two fires. Efforts to maintain burn heterogeneity and its ecological functions can begin with identifying where refugia are likely to occur, using terrain-based microclimate models, burn severity models and available field data.
\end{abstract}

Keywords: refugial gradient; Gaussian kernel; species ordination; generalized additive models; terrain; spatial climate; disturbance interactions; rear edge populations; Pinus ponderosa; burn severity; Las Conchas

\section{Introduction}

Large fires are known to result in a diversity of habitats along a spectrum of change relative to the pre-disturbed landscape [1-4]. Within this heterogeneity, places less affected by fire, including unburnt islands and peninsulas surrounded by the burnt matrix, play a key role in the ongoing function of ecosystems [5,6]. These places serve as refugia during the fire event, by fostering survival of roots and rhizomes, soil and canopy seedbanks and a wide array of species and communities. Following fire, surviving legacies allow repopulation of surrounding areas and ecosystem recovery. Over evolutionary time scales, the diverse ecological functions implicit in refugia hold promise for adaptation to future environmental change $[3,7,8]$.

Various processes underlie the patterns of refugia on burn mosaics. Many studies have focused on identifying refugia through establishing a link to topographic heterogeneity (e.g., [9-11]). Specifically, refugia may be found where fire interacts with stable landscape features that influence microclimate, reduce flammability or create topographic or hydrologic barriers to fire spread [4,12-15]. In many 
cases, refugia occur where topography and fuels are heterogeneous, but in more homogeneous settings, fuel characteristics are more likely to influence patterns of refugia [4]. Stochastic factors including weather during a fire event are also increasingly recognized as an important driver of pattern in post-fire refugia $[4,11,16]$. The relationship between refugia and environment is also mediated by legacies from past fires [17].

A prior disturbance event can drive interactions with subsequent events by altering the inherent resistance or resilience of ecosystem components [17,18]. For example, structural properties of biological legacies from past fires can provide a mechanism for resistance to change in a subsequent fire event (e.g., fine fuel reduction [19]). Moreover, legacy species and communities from one fire event influence recovery in the surrounding landscape [20], altering fuel properties, including spatial connectivity, in the interval between past events and those that follow. Interactions between persistent legacies of past fires, including spatial patterns of refugial habitats, are important drivers of disturbance heterogeneity and ecological response [17,21].

Patterns of refugia following fire have also been defined by specific ecological characteristics and functions. For example, refugial habitats can include old growth forest remnants protected from fire $[9,22]$ that maintain community processes and biodiversity [23]. Refugia may also support species compositions and habitat specialists not found elsewhere on the burn mosaic [24,25], including species that require post-fire seedling recruitment, that is, obligate seeders [26].

Change in remotely sensed indices through time has been used to map patterns of refugia; these indices include a green spot index derived using a time series of Fraction of Absorbed Photosynthetically Active Radiation imagery (MODIS fPAR; $[25,27]$ and the Normalized Burn Ratio derived from spectral bands representative of biomass and moisture content of soil and vegetation, differenced from pre- to post-fire (Landsat TM dNBR; [11,28-30]). Remotely sensed data provide the opportunity to quantify refugial spatial patterns and explore the relationship of those patterns to both underlying processes and ecological functions.

Spatial statistics are commonly used in landscape ecology to visualize spatial trends and quantify spatial pattern and covariance in ecological data [31]. For example, kernel density estimates can be used to convert point data to continuous surfaces showing event density or intensity at varying scales defined by neighborhood size [32]. Kernel surfaces enable identification of neighborhoods with high densities, separated by areas of low density [33]. On burn mosaics, kernel density patterns of refugia represent habitat mosaics with abrupt structural changes from disturbed to undisturbed vegetation. Such structural transitions are important in determining rates of species turnover, providing various spatial configurations of seed sources for re-establishment of vegetation within severely disturbed areas [34]. In addition, the range of kernel densities allows the evaluation of a full spectrum of heterogeneity, from neighborhoods entirely protected from severe fire, to those where higher severity was predominant.

Fire regimes in the Jemez Mountains of northern New Mexico have been the focus of extensive research, due to the unique perspectives gained from the long history of interactions between climate, fire and human activity on this landscape [35-38]. Recent studies have documented rapid and ongoing changes in the landscape ecology of the region following several large fires $[18,20,39]$. The latest of the fires, Las Conchas, burned approximately 63,000 ha in the summer of 2011, including areas burned in several, previous fires [18]. To advance a landscape ecological perspective on these fire events, we pursued the following objectives: (1) quantify spatial patterns of refugia on the Las Conchas burn mosaic using kernel density surfaces; (2) evaluate underlying physical processes that generate those patterns; and (3) develop a link to ecological function by describing the plant communities associated with the spatial patterns. Finally, we explored the spatial dynamics of refugia by examining changes in refugial neighborhoods where the Las Conchas burn mosaic included a past fire event. 


\section{Materials and Methods}

\subsection{Study Area}

The study area is located in northern New Mexico, USA, in the Northwestern Forested Mountains of the Western Cordillera, Southern Rockies ecosystem (Figure 1a,b) [40]. This ecoregion occupies the portion of the Rocky Mountains extending from southern Wyoming, through Colorado and into northern New Mexico. Climate patterns are characterized by fluctuations at a decadal scale influenced by the El Niño Southern Oscillation [41]. Annually, frequent, strong thunderstorms occur during July through early September. Storms in winter (December-March) also bring moisture, but in lesser amounts than received during the summer monsoon. Snow accumulates in winter at elevations $>1500 \mathrm{~m}$; below freezing, overnight lows occur throughout winter and are possible in any season.

The Las Conchas fire in 2011 occurred at the southern end of the ecoregion, in the eastern portion of the Jemez Mountains and on the Pajarito Plateau (longitude $-106.4155^{\circ}$, latitude $35.84923^{\circ}$; Figure $1 \mathrm{a}, \mathrm{b}$ ). Spatial patterns of three older burns were also examined in the present study, in places where these areas were reburned by Las Conchas: La Mesa 1977, Dome 1996 and Cerro Grande 2000 (Figure 1c). The perimeters of the three older burns overlapped in some places. Dome reburned the southern edge of La Mesa, and Cerro Grande reburned La Mesa's northern end. The Las Conchas fire overlapped substantially with the areas burned previously by La Mesa, Dome and Cerro Grande, as well as additional areas outside the older burn perimeters. All four fires occurred during extreme drought, and in each case, drought was preceded by a wetter El Niño period [42]. During the Las Conchas fire, a convergence of weather and fuel conditions led to an extremely rapid rate of spread during the first $13 \mathrm{~h}$ of burning [43].
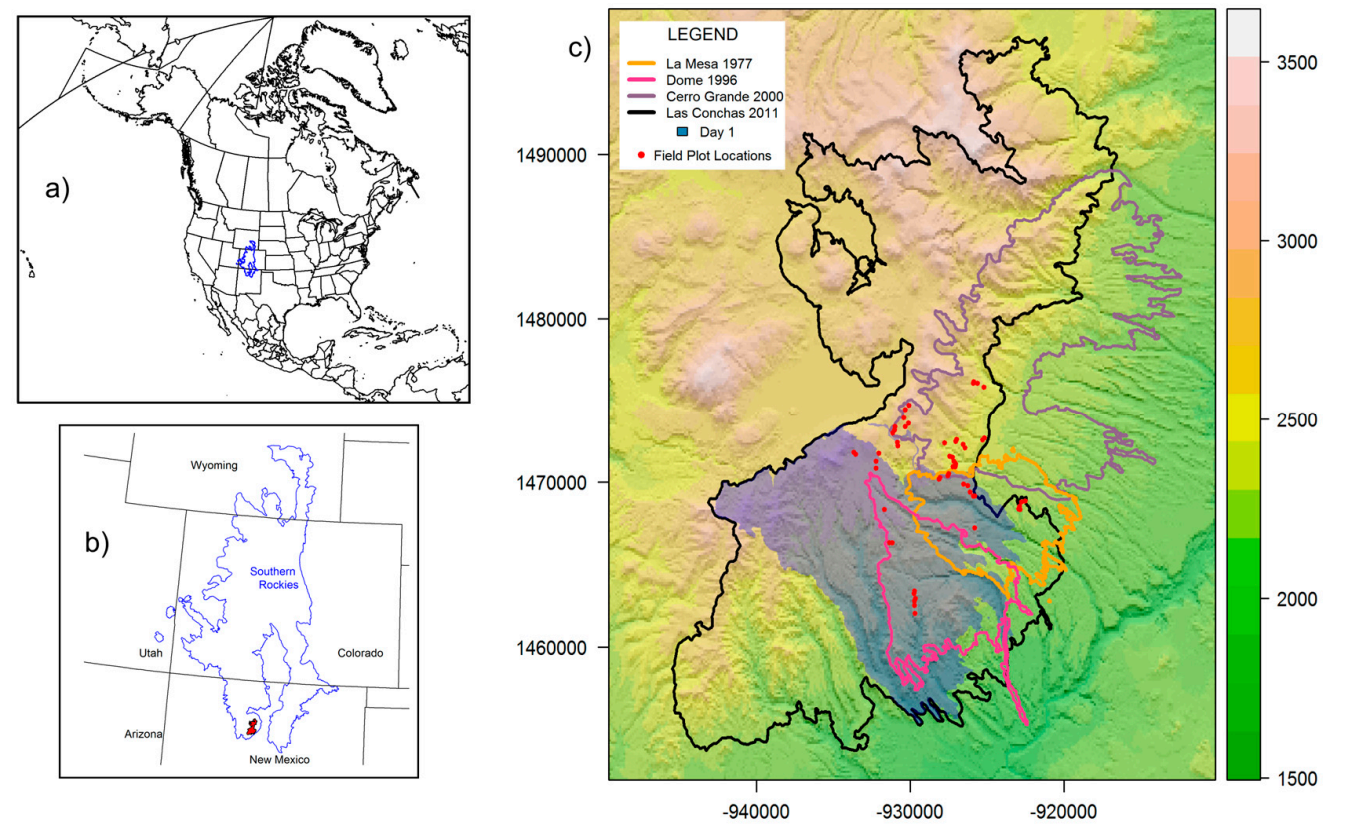

Figure 1. The study area is located at the southern end of the Southern Rockies Ecoregion, North America in northern New Mexico, USA, where several large fires have occurred in recent decades. The Southern Rockies Ecoregion is shown in blue outline in the locator map of North America (a) and in the locator map of the southwestern states (b). The study area is shown in red in map (b). The perimeters of recent fires included in the study are shown with a background of elevation gradient (m) overlaid with hillshades (c). The Las Conchas fire (2011) reburned portions of several previous fires including: La Mesa (1977), Dome (1996) and Cerro Grande (2000). Progress of Las Conchas was rapid in the first day of burning (c; area shaded gray). We used field plot data from Coop et al. (2016; c; red dots). Projection is the Albers Equal Area (units $=\mathrm{m}$ ). 
Topographic variability is dramatic at the edges of steep canyons (Frijoles, Alamo and Capulin) and broad mesas that define the Pajarito Plateau. Ash-flow tuffs, erupted from the Jemez Mountains, define the plateau; its alternating broad mesas and steep canyons drain eastward to White Rock Canyon of the Rio Grande [44]. The San Miguel Mountains, a sub-range of the Jemez, overlap the Dome fire perimeter. Topography within the Cerro Grande fire perimeter is less heterogeneous at lower- to mid-elevations, increasing at mesa-canyon interfaces and with elevation; higher reaches include the Cerro Grande and Pajarito mountains. The area burned during Las Conchas that was outside of the older perimeters included a series of dissected canyons, higher elevation stretches of the Jemez Mountains and a portion of the Valles Caldera to the north and west.

Forest communities generally correspond with changes in elevation. Pinyon-juniper (Pinus edulis-Juniperus spp.) woodlands occur at the lowest elevations; ponderosa pine (P. ponderosa) forests appear as elevation increases. Continuing along the elevational gradient, there is a transition from ponderosa pine to mixed forests composed of two or more tree species, including ponderosa pine, Douglas-fir (Pseudotsuga menziesii), occasional Colorado blue spruce (Picea pungens), white fir (Abies concolor) and some Southwestern white pine (P. strobiformis). Quaking aspen (Populus tremuloides) can be found intermixed or in relatively pure stands. Engelmann spruce (P. engelmannii) occurs at higher elevations. The historical fire regime across these forest and woodland types was composed of a wide range of frequencies and severities that varied with fuels and climate [45,46]. Following the three older fires, the elevational gradient of vegetation communities became more of a patchwork of forested and non-forested vegetation types. For example, 28 years after the 1977 La Mesa fire, severely burned areas were repopulated by assemblages of shrub, grasslands and young trees surrounded by surviving forests $[20,39,47]$. The region's ecology has evolved with human influence including the use of fire and cultivation of plants over thousands of years [37]. Diverse cultures of Native American Pueblos persist in many places, alongside private communities and lands managed by Bandelier National Monument and the Dome Wilderness, the Santa Fe National Forest and the Los Alamos National Laboratory, a United States Department of Energy facility.

\subsection{Las Conchas $R G$}

Within the Las Conchas fire perimeter, we constructed a spatial Refugial Gradient (RG) representing low- to high-density of locations classified as refugia (Figure 2). The classification was based on areas relatively unchanged using a satellite change-detection image (dNBR). The Normalized Burn Ratio (NBR) was calculated using Bands 4 and 7 from pre-fire $(02 / 09 / 2010)$ and post-fire (05/09/2011) Landsat Thematic Mapper images (Path/Row 33/35); the difference was calculated to obtain dNBR (Eidenshink, et al. [48]). Fire perimeters for Las Conchas (Day 1 of burning: 17,654 ha; final perimeter: 61,057 ha) were obtained from the Geosciences and Environmental Change Science Center Outgoing Datasets (GeoMAC website) [49]. Using the change-detection image, we applied a threshold $(-200 \leq \mathrm{dNBR} \leq+200)$ to classify areas of little or no change from pre-fire as refugia (1); all other dNBR values were classified as non-refugia (0). Refugia, defined by the threshold, include low severity in vegetation types that historically had frequent fire, as well as low severity where fire has been less frequent with mixed severity. Then, we applied a Gaussian kernel estimator to the classified map in a moving window approximately 10 ha in size $(11 \times 11$ window; 30-m cells). Specifically, a Gaussian weights matrix defined by its standard deviation $(s d=50$; sum of values $=1$ ) was applied to the 0,1 values in each window, and the sum of the products was assigned to the center cell. The size of the neighborhood over which values are weighted and summed controls the amount of smoothing; small moving windows highlight finer-scale patterns, while larger moving windows reveal broader-scale patterns [31]. We considered a range of neighborhood sizes and settled on the 10-ha scale, because it produced a wide range in patterns, from neighborhoods highly populated (RG values close to or equal to 1 ) to those where refugia were rare (RG values close to 0 ). We used the statistical software R for all computations and analyses, including the analysis of spatial data [50]. Archived data and R code used in the analysis are available (https:/ / doi.org/10.2737/RDS-2017-0005). 

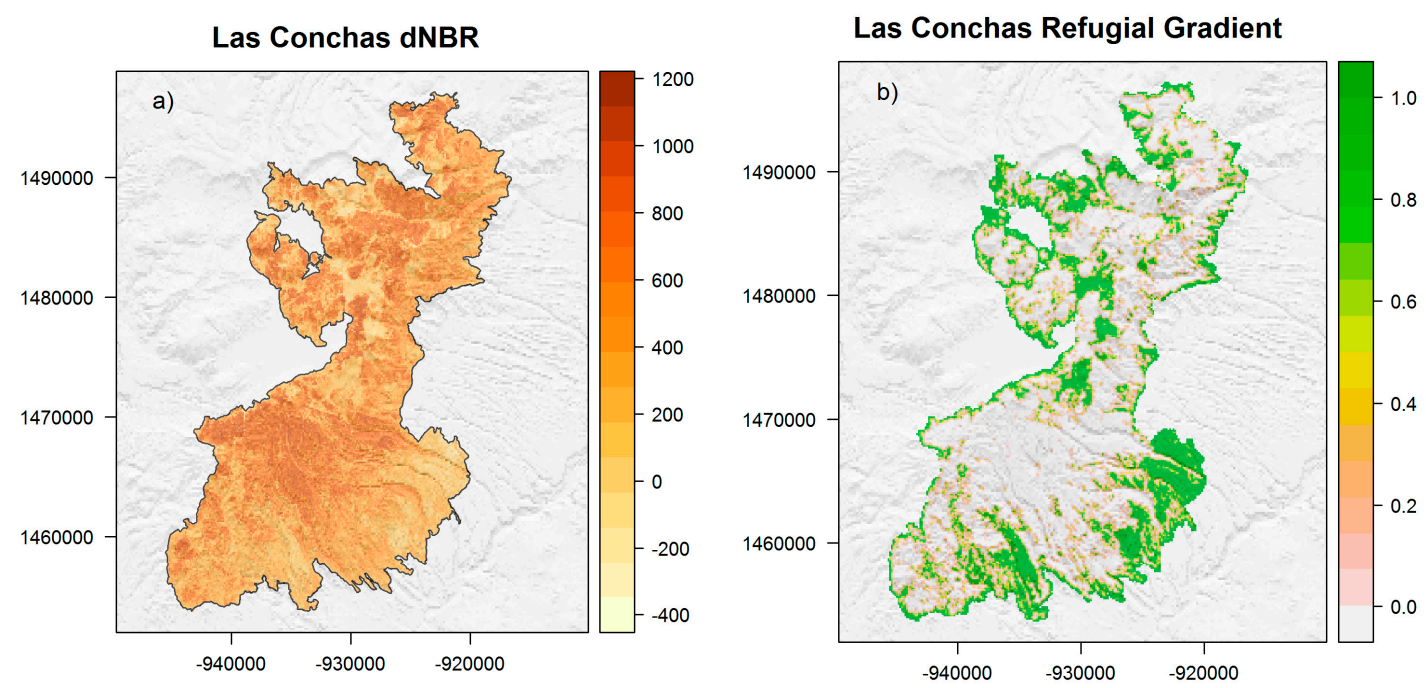

Figure 2. The Refugial Gradient (RG) was defined by the density of locations relatively unchanged from before to after Las Conchas, based on change-detection imagery (differenced Normalized Burn Ratio (dNBR)). Values of dNBR (a) represent a gradient from low (yellow) to high (dark brown) change. The RG (b) represents 10-ha spatial neighborhoods densely populated with refugia (dark green) to those with intermediate to sparse densities (yellow to orange to off-white). The raster images are overlaid with hillshades. Projection is Albers Equal Area (units = meters).

\subsection{Refugial Environments}

We modeled the post-Las Conchas refugial environment using terrain metrics derived from a digital elevation model at 30-m resolution and spatial climate data available for North America [51] (Table 1). The terrain metrics included catchment and local morphometrics, relative position, topographic convergence index, topographic wetness index and wind shelter. All metrics were calculated using raster [52] or RSAGA packages [53,54]. We tested three climate variables $(1-\mathrm{km}$ resolution) in the models: mean annual temperature, mean annual precipitation and number of frost-free days [51].

The goal of the modeling was to associate physical gradients with refugial habitats, measured at the kernel scale $(\sim 10 \mathrm{ha})$, and ultimately to represent the environment in relation to a multivariate community ordination. Thus, the models were meant to describe observed patterns, with the scope of inference limited to the study area. To that end, we sampled the terrain metrics, climate variables and the RG at random locations where the RG value was $>0$ ( 0.1 sample point per ha; $n=3611$ ). First, we compared multiple regression Generalized Additive Models with no interaction terms (GAMs; $\mathrm{R}$ mgcv [55,56]) using four alternative combinations of the terrain metrics: (1) local morphometrics only; (2) catchment metrics only; (3) wetness, convergence and relative position only; and (4) two models that combined significant variables from Models 1 and 2. For local and catchment aspect predictors, we used a circular smoother available in the mgcv::gam function. Wind shelter variables were added one at a time to the best combined model, based on deviance explained, to check for improvement ( $\triangle \mathrm{AIC}>2$; [57]). The climate variables were highly correlated (Pearson's $r>0.8$ ), so we developed three models, each containing only one climate predictor. The RG values followed a continuous distribution with a finite range, consistent with the beta family. We included a factor for random effects as a penalized regression term accounting for markedly different (i.e., more extreme) fire weather during Day 1 of the Las Conchas fire progression. Finally, we tested the usefulness of our final models by comparing statistics (AIC, $p$-values, deviance explained and adjusted $r^{2}$ ) with statistics for null (intercept only) models and models with randomized predictor values. 
Table 1. Spatial variables used to characterize the refugial environment, including terrain metrics derived from a 30-m DEM (calculations were done using R raster [52] and RSAGA [54]) and climate variables mapped at 1-km resolution [51].

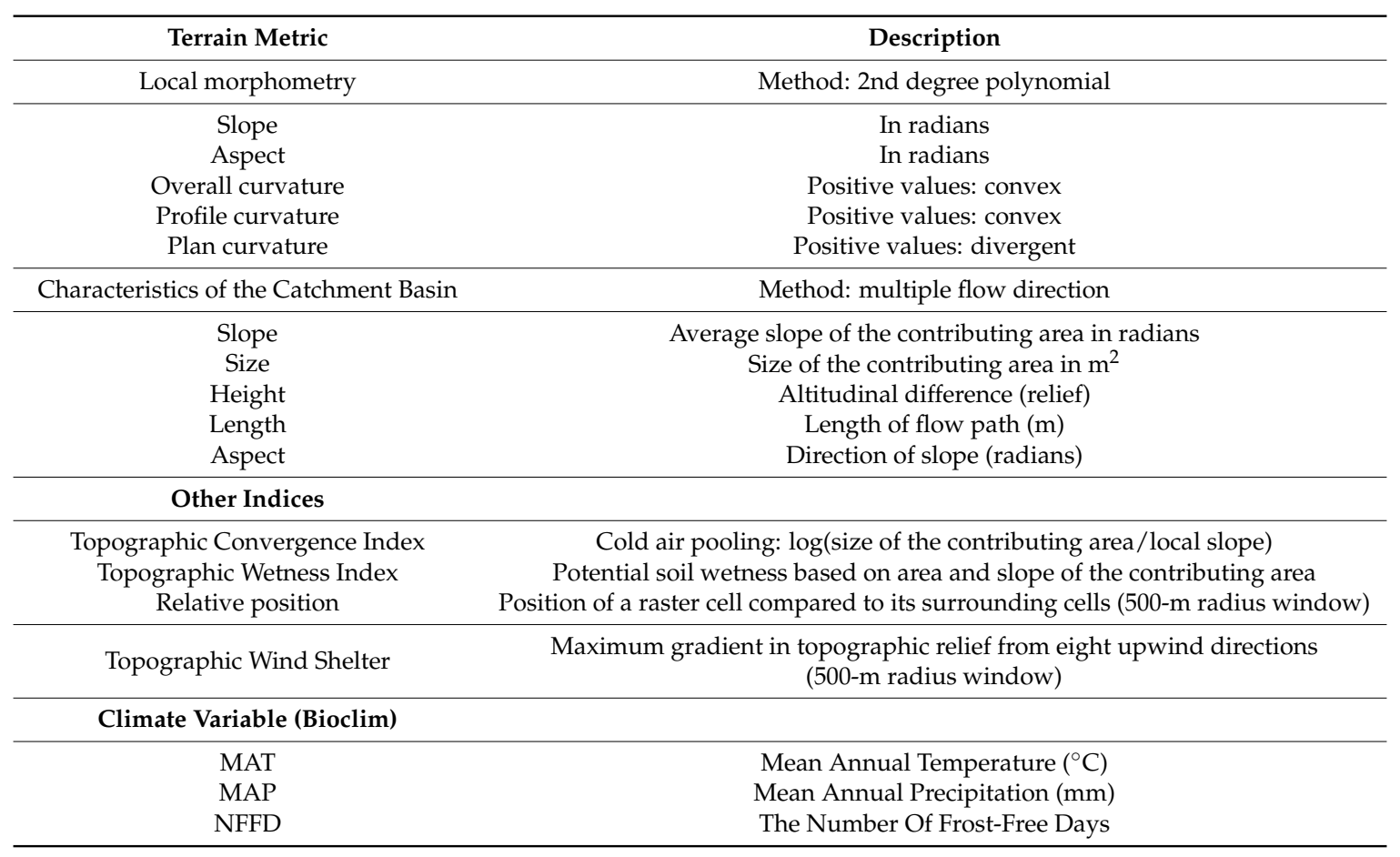

\subsection{Modeling Plant Communities}

To characterize refugial plant communities, we used field data compiled in a recent study of upland vegetation patterns on the Las Conchas landscape [18]. Field data collection was done using sampling protocols in Muldavin et al. [39]; cover was recorded in $20 \times 20-\mathrm{m}$ plots by species and strata (tree, woody plants $\geq 5 \mathrm{~m}$; shrub, woody plants $<5 \mathrm{~m}$, including tree seedlings and saplings; graminoid; and forb). We used two criteria to select field plots for our analysis: first, plots must have been measured post-fire (in either 2013 or 2014), and second, the RG value at that point had to be $>0$. These criteria resulted in 57 plots (Table 2).

Table 2. Spatial data sources, processing methods and field sample count for the four burns. The Las Conchas dNBR image was provided by Steve Howard, US Geological Survey. For Dome and Cerro Grande, dNBR images were downloaded from the Monitoring Trends in Burn Severity website (http://mtbs.gov/). Details for La Mesa image processing (change in Normalized Difference Vegetation Index from pre- to post-fire (dNDVI)) are described in [18] and from Lisa Holsinger, US Forest Service, pers. com. The sample size of field plots within older burn perimeters is given (note: two plots burned in both La Mesa and Cerro Grande); seven plots did not burn in any of the previous fires.

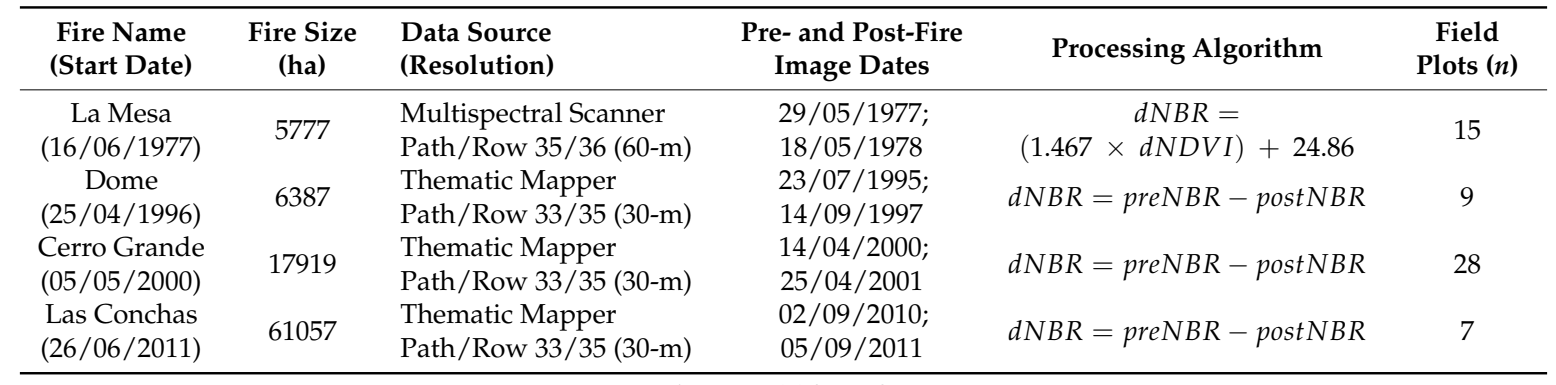


We conducted a Nonmetric Multidimensional Scaling Analysis (NMDS) using a matrix of species cover data (57 sites $\times 159$ species). The process included Wisconsin double standardization with square root transformation of the data; the Bray-Curtis dissimilarity index was used to create the distance matrix ( $\mathrm{R}$ vegan; [58]). We tracked stress over a range of dimensions (1-6) using the default maximum of 20 random starts, and compared results over several independent runs in the search of a stable solution. Then, we fitted a smooth surface to the ordination scores in two dimensions using GAMs, with Las Conchas refugial gradient values as the response and ordination scores from the chosen solution as predictors. We displayed the fitted surface in ordination space to aid interpretation of plant community distributions across refugial environments.

\subsection{Gradient Dynamics}

In order to assess how the refugial neighborhoods had changed from one fire event to another, we constructed spatial refugial gradients for each of the three older burns. Dome and Cerro Grande RGs were derived using the same methods as Las Conchas, described above (Table 2). Because La Mesa pre-dated Landsat Thematic Mapper, dNBR was predicted from Normalized Difference Vegetation Index (dNDVI) values derived using Multispectral Scanner Bands 3 and 4 [18]. We sampled the RGs within the older burn perimeters randomly, and at the 57 field plot locations and used this information to interpret the ordination results relative to past burn event. In addition, we identified where RG values at the field plots had undergone a dramatic shift from one fire to the next, defined by difference in $R G \geq|0.5|$ and described the plant communities in places that had shifted toward more or less densely populated neighborhoods.

\section{Results}

\subsection{Las Conchas RG}

The Las Conchas RG included several areas with high-density neighborhoods (RG $\sim 1$; Figure $2 b$ ). Moderate-density neighborhoods $(0.4<\mathrm{RG}<0.7)$ were scattered throughout the Las Conchas footprint and also typically occurred in zones situated between low and high density neighborhoods. Sparsely inhabited neighborhoods ( $R G<0.4$ ) were also widely distributed, but were most predominant in the northwestern portion of the Day 1 perimeter (refer to Figure 1b), which coincides with a high elevation area of the Jemez Mountains.

\subsection{Refugial Environments}

The RG varied in relation to particular topographic and bioclimatic environments, based on a random sample of locations $(n=3611)$. During model development, we determined that effects of wind shelter were important contributors to combination models $(\triangle \mathrm{AIC}>2)$ in some cases, but not in others, and the direction of influence also varied. Other terrain predictors were either never significant (i.e., catchment height and area; all curvature metrics; relative position) or lost significance in combined models (i.e., catchment flow path length; local aspect and slope; topographic convergence index).

We selected a final terrain model containing catchment slope, catchment aspect and the topographic wetness index. These three predictors were significant $(p<0.05)$ in all multiple regression models that included these variables (i.e., Model 2: catchment metrics only; Model 3: wetness, convergence and relative position only; and Model 4: two models that combined significant variables from Models 1 and 2). The random effects factor representing Day 1 versus other days of fire progression was significant in all model trials. The statistics for the final model with three terrain predictors plus the random effects 'day' factor were: deviance explained $=13 \%$ and adjusted $r^{2}=0.10$. Climate variables were significant predictors of RG when added to the terrain variables $(p<0.001)$. Adding a climate variable to the final terrain model increased the significance of the terrain predictors $(p<0.001)$ and improved overall model fit. Adding either mean annual temperature or mean annual precipitation to the terrain model resulted in deviance explained $=23 \%$ and adjusted $r^{2}=0.18$; 
adding number of frost-free days as a predictor resulted in deviance explained $=21 \%$ and adjusted $r^{2}=0.17$. The final models, with three terrain variables and one climate predictor, represented significant improvement over the null (intercept only) model $\left(\mathrm{AIC}_{\text {final }}>\mathrm{AIC}_{\text {null }}\right)$. Likewise, final models represented a significant improvement over models with randomized predictors. None of the randomized variables were significant at $p<0.05$; deviance explained and adjusted $r^{2}$ were less than 1.0; the randomized models consistently contained less information $\left(\mathrm{AIC}_{\text {final }}>\mathrm{AIC}_{\text {randomized }}\right)$.

Based on the GAM smooth plots for the models with three terrain and one climate predictor, high density neighborhoods occurred on gentle slopes, but low density neighborhoods were more likely on moderate to steep slopes (Figure 3a). Neighborhood density was greater on east-southeasterly aspects (Figure $3 b$ ) and in places with potentially higher soil moisture (Figure 3c). The field plots were located at the lower and mid-range of the catchment slope, but included a fairly wide range of variability in catchment aspect and topographic wetness (top rug on plots in Figure 3a-c).
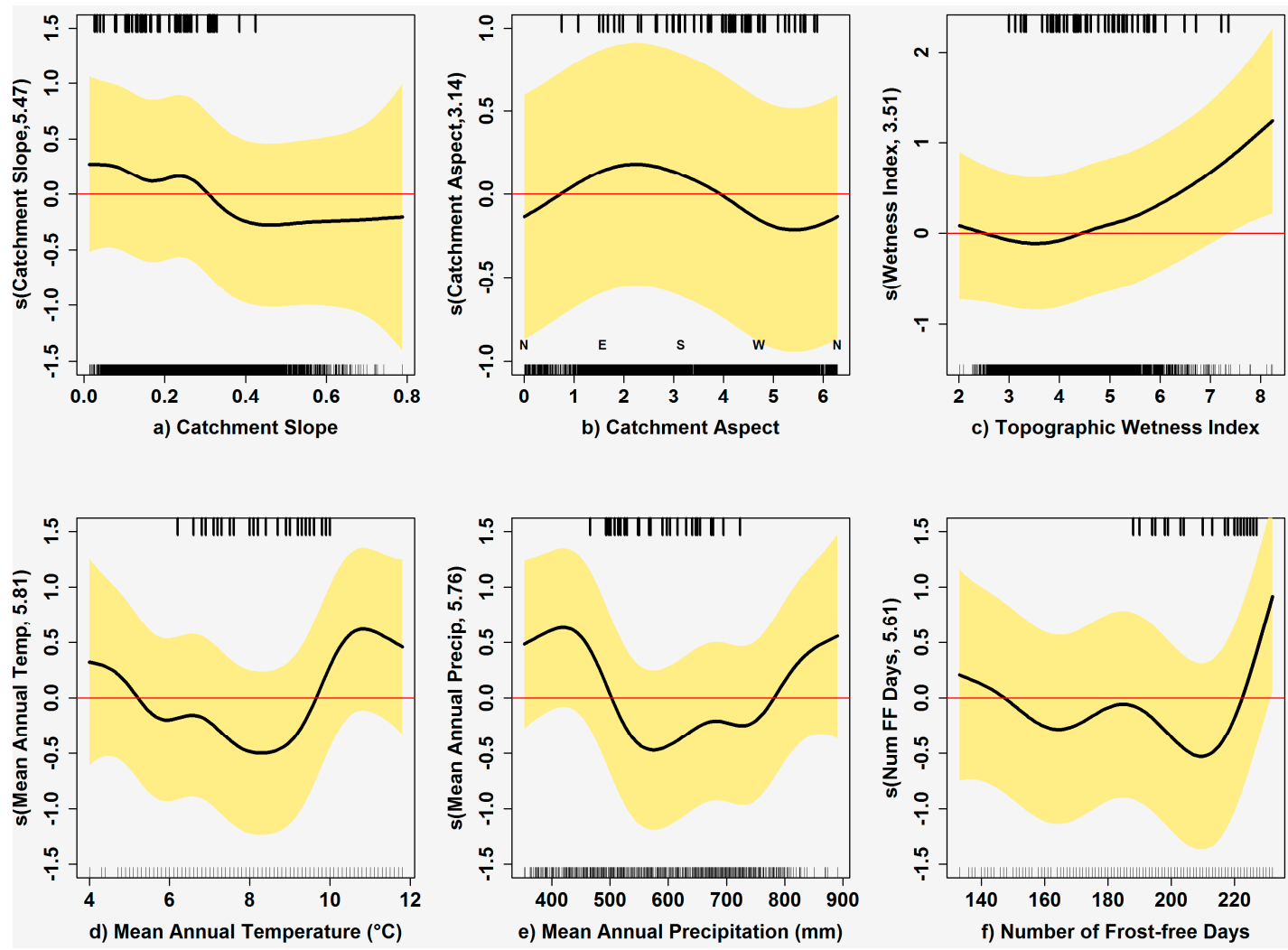

Figure 3. Generalized Additive Model (GAM) smooth plots for the models with three terrain and one climate predictor represent the change in the Refugial Gradient (RG) value (y-axis) relative to variation in terrain and spatial climate ( $x$-axis). Relationships with terrain variables $(\mathbf{a}-\mathbf{c})$ remained the same for all models that included one climate variable. Neighborhoods that were more densely populated with refugia occurred on gentle slopes, but sparsely populated neighborhoods were more likely on moderate and steep slopes (a). Refugia were more abundant in neighborhoods on east-southeasterly aspects (b) and areas with higher soil moisture (c). Greater density of refugia tended to occur at the high and low end of the range in variability in climate $(\mathbf{d}-\mathbf{f})$. Confidence intervals, shaded yellow, include the uncertainty about the overall mean (R-mgcv gam plot option seWithMean = TRUE [55]). Rugs at the bottom of each plot represent the distribution of random samples; the top rugs represent the distribution of field samples.

Refugia increased in density under varied spatial climates (Figure 3d-f). A positive response occurred at low and high ends of the range in temperature, precipitation and length of growing season. The mid-range of the climate variables was more conducive to low density neighborhoods. The field 
plot locations fell in the mid-range of temperature and precipitation, but only represented the upper range of variability in number of frost-free days, compared to the random sample.

\subsection{Community Models}

The ordination revealed a wide distribution of plant assemblages across Las Conchas refugial environments (Figure 4). The two- and three-dimensional NMDS solutions (stress $=0.21$ and 0.19, respectively) showed similar patterns when results were displayed on the modeled surface (GAM fit to NMDS 1 and 2: adjusted $r^{2}=0.12$; deviance explained $=0.38$; and estimated degrees of freedom $=3.86$ ). Most of the field plots were located within the perimeter of one or more past fires (Figure 4a). Those previously burned in Cerro Grande (Figure 4a; purple circles) were located in the left-hand portion of the ordination space, apart from other sites previously burned in La Mesa and Dome in the right-hand portion of the space (orange and violet circles). Among the sample sites, seven occurred in locations that were outside of the older burn perimeters (black circles); these sites were mainly clustered in one region of the ordination space, along the low to mid-range of the RG.
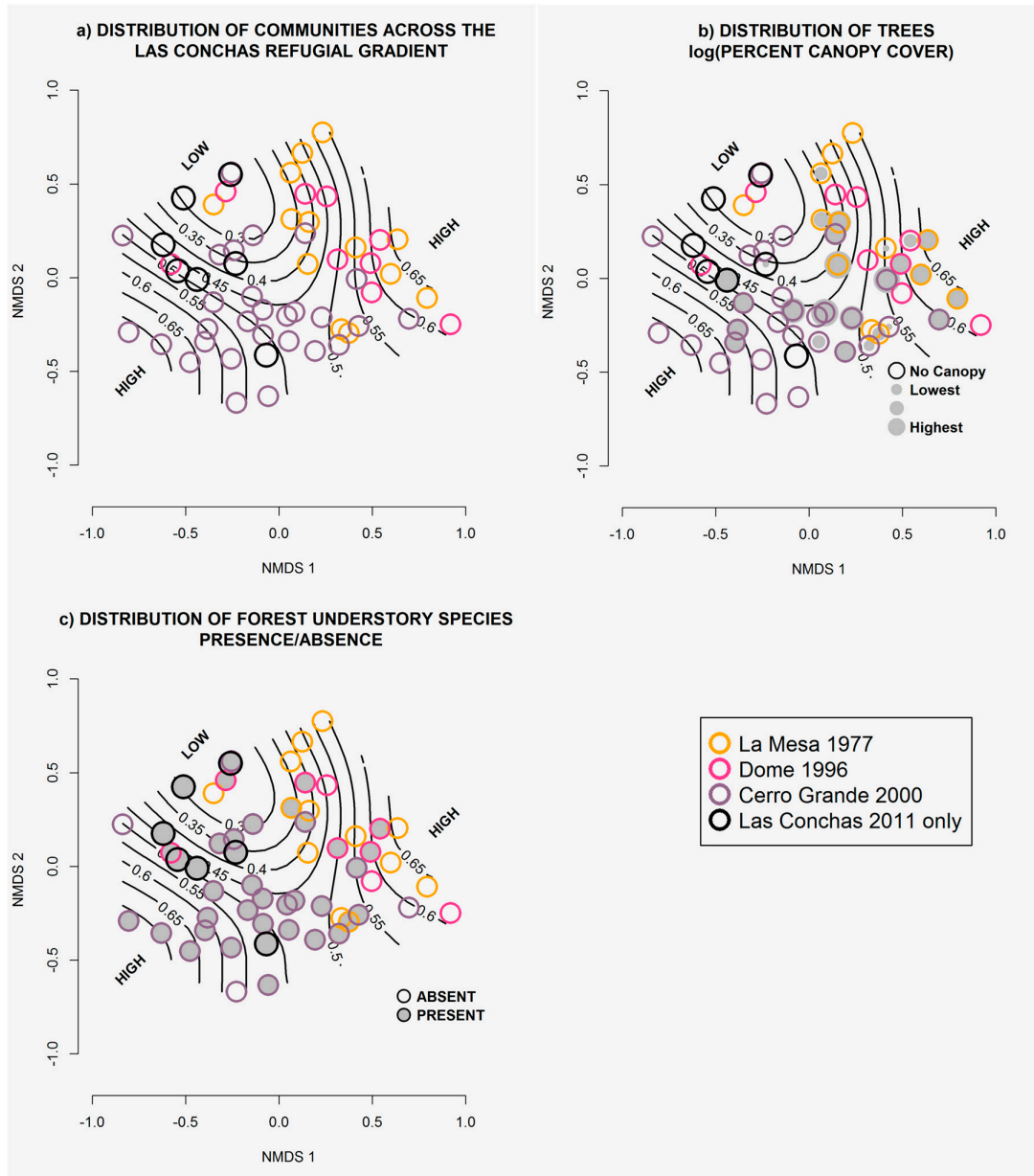

Figure 4. Ordination plots illustrate the distribution of communities in NMDS two-dimensional space (i.e., circles). The environment was modeled using the Las Conchas RG (black contours, direction of gradient is labeled as HIGH-LOW-HIGH). All sites (i.e., field plots) burned in Las Conchas; those that burned in one of the three previous fires are indicated by colored circles $(\mathbf{a}-\mathbf{c})$; those that burned in Las Conchas only are shown as black circles. Communities within the different burns generally overlapped in ordination space (a); trees varied in abundance based on canopy cover (b); one or more species characteristic of the forest understory were present across the gradient, including at some sites with no trees (c). 
Communities exhibited a range of species compositions, including those with few or no trees and shrubby understory, grassy meadows, open canopy forest and rocky substrates with sparse grasses and forbs. To enhance the interpretation of the results, please refer to the table of the 159 species recorded at the 57 field plots (Appendix A). Data include scientific and common names, observed frequency across the field plots, species classifications [59], forest understory designation, and high, medium and low RG classes based on mean value.

Many species were widely distributed across the RG, including species that were abundant, as well as those less frequently observed (Appendix A). For example, beardlip penstemon (Penstemon barbatus), a characteristic understory species of open forests, was present across the full range of refugial neighborhood densities. Ponderosa pine also occurred widely, as did Gambel's oak (Quercus gambelii), New Mexico locust (Robinea neomexicana) and Thurber's fescue (Festuca thurberi). Species linked to forest habitats that were more limited in their distribution included creeping barberry (Mahonia repens), thimbleberry (Rubus parviflorus) and pineywoods geranium (Geranium caespitosum). Greater canopy cover of legacy trees occurred in the medium to high range of the RG (Figure $4 b$ ); species included ponderosa pine, Douglas-fir, white fir and aspen. Forest understory species (Appendix A, denoted by asterisk) were widely distributed across the refugial environments, including some sites where trees were absent (Figure 4c).

\subsection{Gradient Dynamics}

The Las Conchas RG values at the field plots had changed in comparison to gradient values of past fires, but the magnitude and direction of change varied (Figure 5). Out of the 57 sample plots, 88 percent were located within the fire perimeters of La Mesa ( $n=14$; orange circles), Dome ( $n=9$; violet circles) or Cerro Grande ( $n=27$; purple circles). For the 15 plots that previously burned in La Mesa (Figure 5a), the maximum position shift was dramatic in either direction (median change $=-0.11 ; \min =-0.95$, $\max =0.83$ ). For six of these plots, gradient values after Las Conchas were higher (i.e., greater spatial density of refugia). All nine field plots that previously burned in the Dome fire (Figure $5 b$ ) decreased in gradient value after Las Conchas, with dramatic shifts from dense to sparse in a few cases (median change $=-0.50 ; \min =-0.99, \max =-0.08$ ). The 28 plots that previously burned in Cerro Grande (Figure 5c) were also split in direction of change, and similar to La Mesa, there were plots that saw a shift from one end of the gradient to the other (median change $=0.01 ; \min =-0.96, \max =0.98$ ); 17 of these 28 field plots moved to higher positions on the RG after Las Conchas. Only two plots burned at higher severity in past fires (i.e., $R G=0$ ); one at La Mesa and one at Cerro Grande. The patterns of direction of change we observed at the field plots were consistent with a random sample of points within each of the older burns that reburned in Las Conchas (La Mesa, $n=390$; Dome, $n=641$; Cerro Grande, $n=815$; results not shown). Moreover, the gradient values of random points pre-Las Conchas were poorly correlated with values post-Las Conchas (Pearson's $r<0.33$ in all cases).

Some field plots where the RG value increased substantially after Las Conchas (difference $\geq 0.5$ ) were inhabited by trees (i.e., canopy >0: La Mesa: 3 out of 3; Dome 0 out of 0; Cerro Grande 3 out of 5). Several of the plots where the value decreased (difference $\leq-0.5$ ) were also still forested after Las Conchas (La Mesa 2 out of 6; Dome 2 out of 5; Cerro Grande 0 out of 2). Most species were present at one or more plots where the gradient value exhibited a dramatic change after Las Conchas (difference $\geq|0.5|$; Appendix A). Many species were found at plots that experienced a negative change (sparser neighborhood) at some places and a positive change (denser neighborhood) at others, including ponderosa pine, quaking aspen, Rocky Mountain iris (Iris missouriensis) and New Mexico locust. Kingcup cactus (Echinocereus triglochidiatus), pine dropseed (Blepharoneuron tricholepis) and mountain ninebark (Physocarpus monogynus) were examples of species located at one or more field plots that saw a negative shift only; examples of species found at one or more field plots that saw a positive shift only were Douglas-fir, wavyleaf oak (Quercus x pauciloba), mountain mahogany (Cercocarpus montanus) and Colorado barberry (Berberis fendleri). 

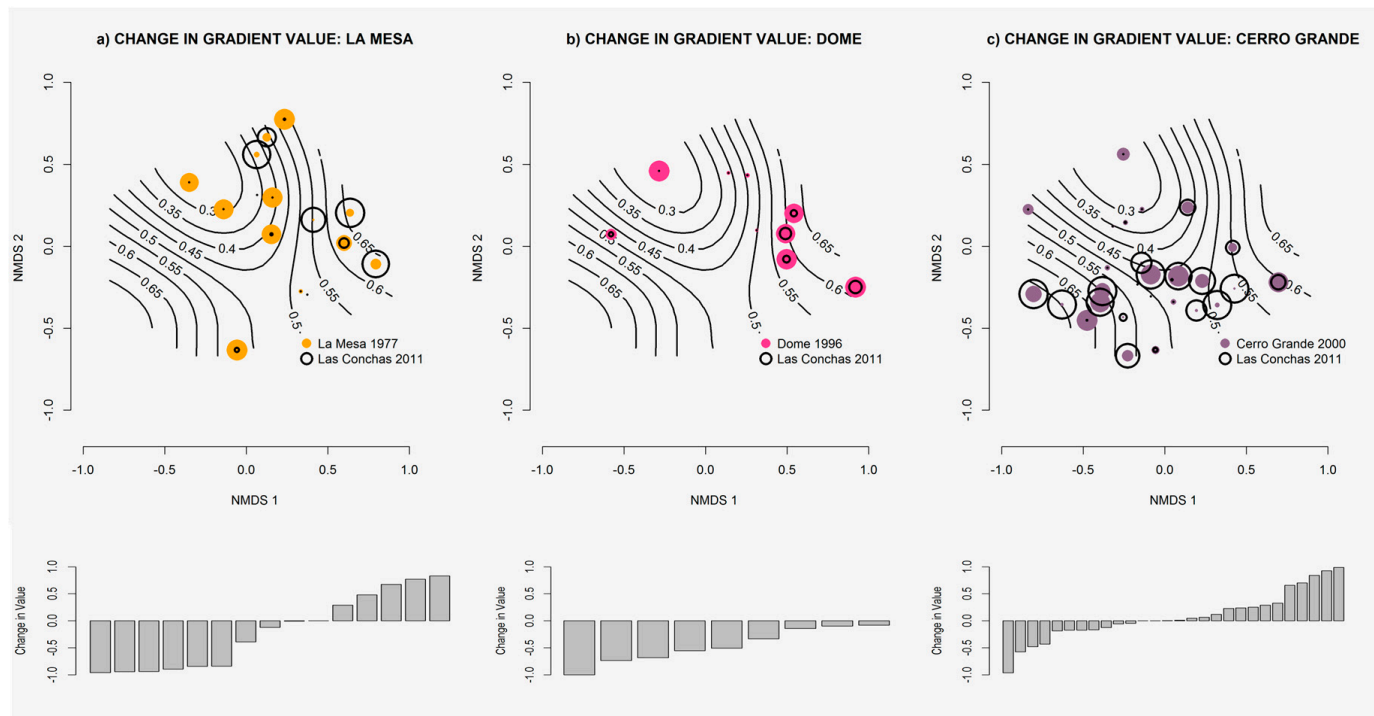

Figure 5. Ordination diagrams and bar charts illustrating refugial neighborhood dynamics following La Mesa (a), Dome (b) and Cerro Grande (c). Circular symbols representing sites are displayed on the Las Conchas RG (black contours), as in Figure 4, but here, site symbols are scaled by RG value for past fires (solid colored circles) and Las Conchas (black open circles). Bar charts below each ordination diagram show the magnitude (height of bar) and direction (distribution of values above or below zero) of change in refugial neighborhood density for each re-burned field plot.

\section{Discussion}

Landscape ecological studies have made significant contributions to understanding the patterns of biological legacies following large disturbance events, notably after the Yellowstone fires of 1988 [60,61]. Here, we qualified patterns of legacies, or refugia, by describing their neighborhood and environmental setting. On the study landscape, we found that refugia occurred in differing spatial densities at the selected scale of measurement; high density neighborhoods were clustered in space, and sparsely populated neighborhoods, including unpopulated areas, occurred in the background matrix (Figure 2).

The scaling of neighborhood patterns of refugia following the Las Conchas fire was correlated with three topographic predictors: slope inclination, aspect and topographic wetness index (Figure 3). Each of these variables may interact with fire behavior in ways that support refugia formation. Refugia were denser at relatively flat sites and places with higher potential soil moisture. In our study region, these settings are generally associated with shifts from upper to lower slope positions, with corresponding increases in soil moisture, finer soil texture, colder temperatures, greater herbaceous cover and reduced tree cover and needle litter [62]. Transitions to wetter and cooler conditions are expected to reduce surface fire line intensity, flame length and crown fire initiation. Likewise, low tree density in these settings apparently did not support active crown fire. Moreover, higher spatial density of refugia often occurred where valley-bottom meadows bordered low-density stands of trees.

Refugia also occurred on moderate to steep slopes, but at lower densities. These locations often support scattered trees above cliffs, talus slopes and on rocky unproductive substrates (J.D. Coop, personal observation), all of which could reduce surface fire intensity, crown fire initiation and spread. Finally, refugia at the high end of the RG on south and east aspects may be related to both grassy openings and low-density stands on south-facing slopes in the study area. The predominant direction of fire spread from west-to-east during Day 1, during which time fire moved uphill (at higher speed and intensity) on west-facing slopes, may have resulted in greater refugia occurrence on south and east slopes, as well. Our observations of refugial environments complement recent findings regarding the importance of topographically-mediated fuel moisture on burn severity in dry forests elsewhere [63,64]. 
In addition, spatial climate influenced patterns of refugia on the post-Las Conchas landscape. Dense configurations (i.e., high RG) were associated with more extreme climates (Figure 3). High and low temperatures generally occur at the extremes of elevation; dense refugia at low elevation included areas that burned previously, in the easterly side of the burn (Figures 1 and 2). Refugia in more scattered configurations (i.e., low RG) were common within the Day 1 perimeter, leading to a logical association of these patterns with extreme fire weather (Figure 2). However, our models indicate that given random effects associated with Day 1 , spatial climate characterized by moderate temperature and precipitation and growing season of intermediate length played a significant role in generating these sparse refugial patterns (Figure 3).

In the context of other research, refugia found in wetter or cooler places conform to common definitions of climate refugia under a warming climate [65], but our observation that spatial patterns of refugia were associated with varied environments motivates the consideration of how refugia function in diverse neighborhoods. The differing spatial density of legacy species and communities could afford both advantages and disadvantages for near-term recovery of severely burnt areas. At the high density end of the RG, post-fire legacies are likely buffered from extreme conditions on the surrounding burn mosaic by other survivors. These buffered habitats may provide favorable conditions for continued survival through plant-soil interactions (e.g., nitrogen availability [66]). Dense neighborhoods may also provide additional opportunities for increased diversity through seed dispersal by wind or animals [67] at local, within-neighborhood scales.

In contrast, widely scattered refugia (i.e., low density neighborhoods) may be more exposed to drying from wind and erosion of soils by wind or water in their immediate neighborhood. Legacies that survive in these more isolated, potentially extreme conditions, however, might be particularly important in advancing reforestation rates. For example, these individuals occupy an advantageous position for the dispersal of seeds into places where soil nutrients have been released by fire $[68,69]$. In the mid-range of the gradient, the ecotones present in mixed neighborhoods (i.e., with a varying proportion of low- to high-severity context) have been found to represent a diversity of resources and habitats that support important ecological functions [69-72].

The presence of trees and forest associates even at the low end of the RG appears encouraging for forest recovery (Figure 4; Appendix A), but studies indicate that repopulation of the surrounding landscape in the near term may be limited due to drought conditions [73] and competition from early post-fire resprouting shrubs [74]. The long-term protection of seedbanks, through topographically defined microclimates [65], as well as active management may be necessary to maintain these refugial populations until conditions in the surrounding landscape become more favorable for forest species.

Although forest species are of great interest, refugia comprised of non-forest species deserve equal attention for their role in ecosystem function [75]. The species we observed included both forest and non-forest species that hold important traditional uses among Pueblo peoples, including Colorado barberry, Carruth's sagewort (Artemisia carruthii), ragleaf bahia (Bahia dissecta) and many others [37]. Grass and shrub species, present across the RG (Appendix A), are often found in the surrounding burned matrix and tend to persist through multiple fire events by rebounding quickly [18]. Where meadows and shrublands are protected from severe fire, these communities may harbor legacies, including seedbanks of obligate seeders (including the conifer trees found in the region), and may provide habitat for animal seed dispersers $[34,76]$. The montane meadows we observed can be rich in biodiversity and serve as indicators of environmental change [77,78]. Furthermore, early successional grassy openings created by fire have been observed to transition to young forests in some places [20].

Our field sampling excluded riparian areas, but the map of the refugial gradient reveals that refugia occurred in riparian environments on the Las Conchas landscape along creeks such as El Rito de Los Frijoles. In other studies, riparian areas served as refugia for P. sabiniana in the southern Sierra Nevada, California, USA, enabling pines to recolonize severely-burned areas during fire-free intervals [79]. In frequent-fire environments of southeastern Australia, gullies were found to play 
a role in preserving heterogeneity in forest structure [15]. These wetter, cooler areas may be critical climate and fire refugia in rapidly-changing environments [80].

Refugial habitats, overall, are expected to change through time, in both form and function [80]. At Las Conchas, forest remnants experienced both increases and decreases in neighborhood refugial density in comparison to past fires. It is possible that some of these increases may be due to post-fire tree regeneration that occurred between fire events, particularly where increases occurred between the 1977 La Mesa fire and 2011. Recolonization of these landscapes has been found to result from the migration of regenerating trees from the edge of surviving trees in a wave-form succession [47]; with sufficient time since fire and favorable climate conditions for germination and growth, young trees may have reached sufficient stature to survive after the Las Conchas fire and thus increased the size of refugia. Decreasing density of refugia may occur in places where mechanisms such as environmental setting (e.g., cooler or wetter microclimates; topographic position) are insufficient to maintain patterns of refugia observed following earlier fire events. Furthermore, protection afforded by terrain can be lessened under severe fire weather [11].

Most of the refugial neighborhoods after Las Conchas coincided with refugia after a previous fire (Figure 5), indicating that these refugia persisted through at least two fires. Environments and associated communities may differ within particular burn events and with fire intervals, as evidenced by the separation of sites in ordination space that burned in Cerro Grande from those burned in La Mesa and Dome (Figure 4). Likely mechanisms for persistence of refugia include topographic setting (Figure 3), such as wetter environments and steep, grassy slopes with scattered trees on Cerro Grande, Pajarito and other mountains. Burn patterns from the 2000 Cerro Grande fire were important contributors to successful containment efforts during the 2011 Las Conchas fire [81]; knowledge of these interactions can be used to promote a persistent template of refugia defined by particular physical environments and species compositions.

Our results indicate that when a neighborhood increases or decreases in density of refugia, habitats and their inhabitants may also change. A wide variety of species were represented at locations that became more or less populated by refugia. The implications of this observation need further investigation, to understand each species' independent response to its changing neighborhood environment and the resulting complex dynamics [82]. Species interactions and dispersal patterns, as well as habitat parameters (e.g., temperature and water availability) likely change with neighborhood context.

For many of the species we observed, including several tree species, our study area at the southern end of the Rocky Mountains is located at the rear edge, or the lower latitudinal margin of their geographic distribution. As climate change creates shifts in species distributions, the persistence of rear edge populations may depend on areas of greater climatic stability that occur in regions of diverse topography [80]. Stressors including drought [83] and fire [73] limit the distribution of vulnerable species to refugial environments $[80,84]$. Identifying the regional context of refugia within burn mosaics is important to gaining a broader view of places protected from changing climate and disturbance regimes $[76,85]$.

\section{Conclusions}

The landscape ecological perspective we adopted illustrates one approach to understanding refugia and their role in the ecological functioning of post-fire landscapes. Alternative perspectives, definitions and models will continue to emerge, based on studies conducted in different locations and at varying spatial scales. Moreover, examining additional factors that interact to define refugial environments remains a key priority and could serve to improve the limited explanatory power of the models we developed specifically for our study landscape. These factors include the temporal progress of burning and associated fire weather that have been shown to shape refugial environments [11]. Future development and tests of new indices derived from remotely sensed data could also result in improved understanding of refugial characteristics following fire events. 
Refugia on burn mosaics are increasingly acknowledged as a key resource for recovery and adaptation to change that needs to be protected and maintained [12,23,72,76,86]. However, widespread efforts to exclude, mitigate or contain severe fire through forest thinning, suppression and fire-fighting activities (including back-burning), as well as efforts to speed recovery from severe fire do not currently incorporate knowledge of existing or potential refugia on managed landscapes [87]. Large areas of tree mortality can easily dominate the early post-fire perspective in the absence of a quantitative assessment of burn heterogeneity and associated ecological functions.

Recognizing where refugia are likely to occur following fire could aid in maintaining burn heterogeneity and prevent severe degradation of refugial resources. We recommend starting with a coarse-filter based on the physical template. Terrain metrics that indicate microclimates where refugia tend to form in mountains [65] are easily computed from digital elevation models using open source software and code, such as R [50]. These spatial metrics can be viewed in conjunction with burn severity models; by applying a range of low-change thresholds, potential refugia can be identified.

Additionally, surveys of old growth forest structure [88] and species requiring specialized habitats protected from severe fire (e.g., Jemez Mountain salamander [89]) can also be taken as indicators of refugia on disturbed or undisturbed landscapes. We concur with recommended conservation measures considering the potential impacts of climate change that include maintenance of the greatest possible number of local refugia as habitat networks [25]. In this way, the potential contribution of refugia to regional diversity and landscape resilience under different future scenarios could be maximized [80,90].

Acknowledgments: Thanks to Steve Howard, who provided the Las Conchas dNBR image; Sean Parks, Lisa Holsinger, and Sarah McClernan for work on the reburning project; Ethan Plunkett, UMass Landscape Ecology Lab for developing and sharing R code, including kernel functions. This work was supported by a Research Joint Venture Agreement between the USDA Forest Service Rocky Mountain Research Station and the Haire Laboratory. We also gratefully acknowledge the ongoing support of our home institutions.

Author Contributions: All authors conceived of and designed the experiments. Sandra Haire performed the experiments and analyzed the data. Jonathan Coop contributed field data and imagery for La Mesa. All authors contributed to writing the paper.

Conflicts of Interest: The authors declare no conflict of interest. The founding sponsors had no role in the design of the study; in the collection, analyses or interpretation of data; in the writing of the manuscript; nor in the decision to publish the results. 


\section{Appendix}

Table A1. Species recorded at the 57 field plots $(n=159)$, including scientific and common names. Additional information includes: forest understory designation (marked with an asterisk), species classifications (Foxx and Hoard 1995), observed frequency across sites, Las Conchas refugial gradient value (mean, min, max) and high, medium and low refugial gradient classes based on mean value (high $\geq 0.7$; medium 0.4 to 0.7 ; low $<0.4$ ). Please note: minimum gradient values are truncated to two decimal places, so zero values are actually $>0$, but $<0.001$. Species observed at one or more field sites where the gradient value had shifted dramatically (i.e., $\geq|0.5|$ ) since the previous fire are indicated with a symbol following the gradient mean class: $(+)=$ higher post-Las Conchas; $(-)=$ lower post-Las Conchas; $(+/-)=$ observed at some sites with an increased value and some with a decreased value. The remainder of species were not observed at places with extreme shifts or were only recorded in places that had not burned in the La Mesa, Dome or Cerro Grande fires. Nomenclature follows: USDA, Natural Resources Conservation Service, 2017. The PLANTS Database (http:/ / plants.usda.gov, 10 February 2017). National Plant Data Team, Greensboro, NC 27401-4901 USA.

\begin{tabular}{|c|c|c|c|c|c|c|}
\hline \multirow{2}{*}{$\begin{array}{c}\text { Scientific Name } \\
\text { Allium geyeri }\end{array}$} & \multirow{2}{*}{$\begin{array}{l}\text { Common Name } \\
\text { Geyer's onion }\end{array}$} & \multicolumn{2}{|c|}{ Foxx and Hoard 1995 Class } & \multirow{2}{*}{$\begin{array}{c}\text { Frequency (\%) } \\
0.02\end{array}$} & \multirow{2}{*}{$\begin{array}{c}\begin{array}{c}\text { Gradient Value } \\
\text { Mean (min, max) }\end{array} \\
0.83(0.83,0.83)\end{array}$} & \multirow{2}{*}{$\begin{array}{c}\text { Gradient Mean Class } \\
\text { high }\end{array}$} \\
\hline & & herbaceous & showy monocots & & & \\
\hline Artemisia carruthii & Carruth's sagewort & herbaceous & composites & 0.07 & $0.8(0.35,1)$ & $\operatorname{high}(+)$ \\
\hline Artemisia dracunculus & tarragon & herbaceous & composites & 0.09 & $0.75(0.08,1)$ & high $(+)$ \\
\hline Grindelia squarrosa & curly-cup gumweed & herbaceous & composites & 0.02 & $0.72(0.72,0.72)$ & high $(+)$ \\
\hline Hymenoxys acaulis * & perky sue & herbaceous & composites & 0.02 & $1(1,1)$ & high $(+)$ \\
\hline Solidago nemoralis var. decemflora & goldenrod & herbaceous & composites & 0.02 & $0.72(0.72,0.72)$ & high $(+)$ \\
\hline Andropogon gerardii & big bluestem & herbaceous & grasses & 0.07 & $0.72(0.09,1)$ & $\operatorname{high}(+/-)$ \\
\hline Elymus spp. & wildrye & herbaceous & grasses & 0.02 & $0.93(0.93,0.93)$ & high \\
\hline Festuca thurberi & Thurber's fescue & herbaceous & grasses & 0.09 & $0.79(0.04,1)$ & $\operatorname{high}(+/-)$ \\
\hline Lycurus setosus & bristly wolfstail & herbaceous & grasses & 0.02 & $1(1,1)$ & high \\
\hline Carex praegracilis & clustered field sedge & herbaceous & rushes and sedges & 0.05 & $1(1,1)$ & $\operatorname{high}(+)$ \\
\hline Arenaria lanuginosa ssp. saxosa & spreading sandwort & herbaceous & showy dicots & 0.04 & $0.97(0.94,1)$ & high \\
\hline Campanula rotundifolia & bluebell bellflower & herbaceous & showy dicots & 0.12 & $0.8(0.05,1)$ & high \\
\hline Erigeron formosissimus & beautiful fleabane & herbaceous & composites & 0.02 & $1(1,1)$ & high \\
\hline Frasera speciosa & showy frasera & herbaceous & showy dicots & 0.02 & $1(1,1)$ & $\operatorname{high}(+)$ \\
\hline Ipomopsis aggregata & skyrocket gilia & herbaceous & showy dicots & 0.02 & $1(1,1)$ & high $(+)$ \\
\hline Lupinus argenteus & silvery lupine & herbaceous & showy dicots & 0.04 & $0.89(0.83,0.96)$ & high \\
\hline Sisymbrium altissimum & tall tumblemustard & herbaceous & showy dicots & 0.02 & $0.81(0.81,0.81)$ & high \\
\hline Trifolium wormskioldii & cows clover & herbaceous & showy dicots & 0.07 & $0.72(0,1)$ & high \\
\hline Abies concolor & white fir & woody & trees & 0.07 & $0.81(0.49,1)$ & high \\
\hline Quercus x pauciloba & wavyleaf oak & woody & shrub & 0.09 & $0.7(0.02,1)$ & $\operatorname{high}(+)$ \\
\hline Echinocereus triglochidiatus & kingcup cactus & herbaceous & cacti & 0.02 & $0.45(0.45,0.45)$ & medium $(-)$ \\
\hline Achillea millefolium & common yarrow & herbaceous & composites & 0.46 & $0.4(0,1)$ & medium $(+/-)$ \\
\hline Antennaria spp. & pussytoes & herbaceous & composites & 0.14 & $0.5(0.01,1)$ & medium $(+)$ \\
\hline Antennaria parvifolia & smallleaf pussytoes & herbaceous & composites & 0.04 & $0.4(0.09,0.72)$ & medium $(+/-)$ \\
\hline
\end{tabular}


Table A1. Cont.

\begin{tabular}{|c|c|c|c|c|c|c|}
\hline \multirow{2}{*}{$\begin{array}{c}\text { Scientific Name } \\
\text { Brickellia eupatorioides var. chlorolepis }\end{array}$} & \multirow{2}{*}{$\begin{array}{c}\text { Common Name } \\
\text { false boneset }\end{array}$} & \multicolumn{2}{|c|}{ Foxx and Hoard 1995 Class } & \multirow{2}{*}{$\begin{array}{c}\text { Frequency }(\%) \\
0.07\end{array}$} & \multirow{2}{*}{$\begin{array}{c}\begin{array}{c}\text { Gradient Value } \\
\text { Mean (min, max) }\end{array} \\
0.61(0,1)\end{array}$} & \multirow{2}{*}{$\frac{\text { Gradient Mean Class }}{\text { medium }(+)}$} \\
\hline & & herbaceous & composites & & & \\
\hline Brickellia grandiflora & tasselflower brickellbush & herbaceous & composites & 0.04 & $0.58(0.16,1)$ & medium $(+)$ \\
\hline Heterotheca villosa & false goldenaster & herbaceous & composites & 0.23 & $0.58(0,1)$ & medium $(+/-)$ \\
\hline Laennecia schiedeana & pineland marshtail & herbaceous & composites & 0.07 & $0.48(0.06,0.97)$ & medium $(+/-)$ \\
\hline${ }^{1}$ Oreochrysum parryi & Parry's goldenrod & herbaceous & composites & 0.19 & $0.49(0,1)$ & medium $(+)$ \\
\hline Solidago missouriensis & Missouri goldenrod & herbaceous & composites & 0.07 & $0.4(0,0.72)$ & medium $(+)$ \\
\hline Bouteloua gracilis & blue grama & herbaceous & grasses & 0.09 & $0.46(0,1)$ & medium $(+/-)$ \\
\hline Danthonia parryi & Parry's oatgrass & herbaceous & grasses & 0.18 & $0.5(0,1)$ & medium $(+/-)$ \\
\hline Elymus elymoides & bottlebrush squirreltail & herbaceous & grasses & 0.30 & $0.49(0,1)$ & medium $(+/-)$ \\
\hline Elymus trachycaulus & slender wheatgrass & herbaceous & grasses & 0.18 & $0.55(0,1)$ & medium $(+)$ \\
\hline Koeleria macrantha & prairie junegrass & herbaceous & grasses & 0.32 & $0.46(0,1)$ & medium $(+/-)$ \\
\hline Muhlenbergia montana & mountain muhly & herbaceous & grasses & 0.42 & $0.5(0,1)$ & medium $(+/-)$ \\
\hline Muhlenbergia ramulosa & green muhly & herbaceous & grasses & 0.02 & $0.45(0.45,0.45)$ & medium (-) \\
\hline Poa fendleriana & muttongrass & herbaceous & grasses & 0.30 & $0.56(0,1)$ & medium $(+/-)$ \\
\hline Carex spp.-upland small & sm. upland sedge $<25 \mathrm{~cm}$ & herbaceous & rushes and sedges & 0.12 & $0.65(0.01,1)$ & medium $(+/-)$ \\
\hline${ }^{1}$ Carex occidentalis & western sedge & herbaceous & rushes and sedges & 0.09 & $0.63(0,1)$ & medium $(+/-)$ \\
\hline${ }^{1}$ Carex siccata & dryspike sedge & herbaceous & rushes and sedges & 0.25 & $0.48(0,1)$ & medium $(+/-)$ \\
\hline Arenaria fendleri & Fendler's sandwort & herbaceous & showy dicots & 0.04 & $0.59(0.35,0.83)$ & medium \\
\hline Castilleja miniata & scarlet Indian paintbrush & herbaceous & showy dicots & 0.04 & $0.5(0.04,0.96)$ & medium $(-)$ \\
\hline Erigeron divergens & spreading fleabane & herbaceous & composites & 0.02 & $0.45(0.45,0.45)$ & medium $(-)$ \\
\hline Erigeron flagellaris & trailing fleabane & herbaceous & composites & 0.12 & $0.43(0,1)$ & medium $(-)$ \\
\hline Erigeron subtrinervis & threenerve fleabane & herbaceous & composites & 0.05 & $0.56(0.04,0.83)$ & medium $(-)$ \\
\hline Erysimum capitatum & sanddune wallflower & herbaceous & showy dicots & 0.09 & $0.43(0,0.97)$ & medium $(+/-)$ \\
\hline${ }^{1}$ Fragaria vesca & woodland strawberry & herbaceous & showy dicots & 0.09 & $0.44(0,1)$ & medium $(-)$ \\
\hline Galium aparine & stickywilly & herbaceous & showy dicots & 0.04 & $0.42(0.04,0.81)$ & medium $(-)$ \\
\hline Galium boreale & Northern bedstraw & herbaceous & showy dicots & 0.04 & $0.5(0.01,1)$ & medium \\
\hline Lathyrus lanszwertii & Nevada peavine & herbaceous & showy dicots & 0.16 & $0.44(0,1)$ & medium $(+/-)$ \\
\hline Oxalis violacea & violet woodsorrel & herbaceous & showy dicots & 0.02 & $0.45(0.45,0.45)$ & medium $(-)$ \\
\hline Potentilla hippiana & woolly cinquefoil & herbaceous & showy dicots & 0.21 & $0.6(0,1)$ & medium $(+/-)$ \\
\hline Pseudocymopterus montanus & alpine false springparsley & herbaceous & showy dicots & 0.04 & $0.52(0.09,0.96)$ & medium $(-)$ \\
\hline Thermopsis montana var. montana & mountain goldenbanner & herbaceous & showy dicots & 0.18 & $0.41(0,1)$ & medium $(+/-)$ \\
\hline ** Chenopodium graveolens & fetid goosefoot & herbaceous & herbaceous dicots & 0.11 & $0.45(0.06,0.93)$ & medium $(+/-)$ \\
\hline Chenopodium leptophyllum & narrowleaf goosefoot & herbaceous & herbaceous dicots & 0.04 & $0.49(0.18,0.81)$ & medium \\
\hline Iris missouriensis & Rocky Mountain iris & herbaceous & showy monocots & 0.18 & $0.66(0,1)$ & medium $(+/-)$ \\
\hline${ }^{1}$ Arctostaphylos uva-ursi & kinnikinnick & woody & shrubs & 0.18 & $0.45(0.01,1)$ & medium $(+/-)$ \\
\hline Berberis fendleri & Colorado barberry & woody & shrubs & 0.04 & $0.49(0,0.97)$ & medium $(+)$ \\
\hline Brickellia californica & California brickellbush & woody & shrubs & 0.04 & $0.62(0.26,0.99)$ & medium $(+)$ \\
\hline
\end{tabular}


Table A1. Cont.

\begin{tabular}{|c|c|c|c|c|c|c|}
\hline \multirow{3}{*}{$\begin{array}{c}\text { Scientific Name } \\
\begin{array}{c}\text { Cercocarpus montanus } \\
\text { Jamesia americana }\end{array}\end{array}$} & \multirow{2}{*}{$\begin{array}{c}\text { Common Name } \\
\text { mountain mahogany }\end{array}$} & \multicolumn{2}{|c|}{ Foxx and Hoard 1995 Class } & \multirow{2}{*}{$\begin{array}{c}\text { Frequency (\%) } \\
0.04\end{array}$} & \multirow{2}{*}{$\begin{array}{c}\begin{array}{c}\text { Gradient Value } \\
\text { Mean (min, max) }\end{array} \\
0.43(0,0.85)\end{array}$} & \multirow{2}{*}{$\begin{array}{c}\text { Gradient Mean Class } \\
\text { medium }(+)\end{array}$} \\
\hline & & woody & shrubs & & & \\
\hline & cliffbush & woody & shrubs & 0.04 & $0.51(0.05,0.97)$ & medium $(+)$ \\
\hline Sambucus spp. & elderberry & woody & shrubs & 0.07 & $0.48(0.05,1)$ & medium $(+)$ \\
\hline Pinus ponderosa & ponderosa pine & woody & trees & 0.40 & $0.57(0,1)$ & medium $(+/-)$ \\
\hline Populus tremuloides & quaking aspen & woody & trees & 0.28 & $0.46(0,1)$ & medium $(+/-)$ \\
\hline Pseudotsuga menziesii & Douglas-fir & woody & trees & 0.12 & $0.56(0,0.97)$ & medium $(+)$ \\
\hline Agoseris aurantica & orange agoseris & herbaceous & composites & 0.02 & $0(0,0)$ & low $(-)$ \\
\hline Allium cernuum & nodding onion & herbaceous & showy monocots & 0.14 & $0.3(0,1)$ & low $(-)$ \\
\hline Antennaria marginata & whitemargin pussytoes & herbaceous & composites & 0.02 & $0.18(0.18,0.18)$ & low \\
\hline Artemisia franserioides & ragweed sagebrush & herbaceous & composites & 0.02 & $0.04(0.04,0.04)$ & low $(+)$ \\
\hline Artemisia ludoviciana & white sagebrush & herbaceous & composites & 0.26 & $0.36(0,0.93)$ & low $(+/-)$ \\
\hline Aster spp. & aster & herbaceous & composites & 0.02 & $0.18(0.18,0.18)$ & low \\
\hline Bahia dissecta & ragleaf bahia & herbaceous & composites & 0.25 & $0.39(0,1)$ & low $(+/-)$ \\
\hline Brickelliastrum fendleri & Fendler's brickellbush & herbaceous & composites & 0.02 & $0(0,0)$ & low \\
\hline Cirsium pallidium & pale thistle & herbaceous & composites & 0.16 & $0.22(0,0.81)$ & low $(+)$ \\
\hline Cirsium spp. & thistle & herbaceous & composites & 0.04 & $0.37(0.02,0.72)$ & low $(+)$ \\
\hline Cirsium undulatum & wavyleaf thistle & herbaceous & composites & 0.02 & $0.04(0.04,0.04)$ & low \\
\hline Conyza canadensis & Canadian horseweed & herbaceous & composites & 0.14 & $0.3(0.01,0.99)$ & low $(+/-)$ \\
\hline Hymenoxys richardsonii & pingue hymenoxys & herbaceous & composites & 0.02 & $0.35(0.35,0.35)$ & low \\
\hline Lactuca serriola & prickly lettuce & herbaceous & composites & 0.04 & $0.1(0.04,0.16)$ & low $(-)$ \\
\hline Packera fendleri & Fendler's ragwort & herbaceous & composites & 0.05 & $0.32(0.25,0.45)$ & low $(-)$ \\
\hline Pericome caudata & mountain leaftail & herbaceous & composites & 0.02 & $0.05(0.05,0.05)$ & low \\
\hline Pseudognaphalium macounii & Macoun's cudweed & herbaceous & composites & 0.02 & $0.35(0.35,0.35)$ & low \\
\hline${ }^{1}$ Senecio bigloviii & nodding ragwort & herbaceous & composites & 0.05 & $0.16(0.08,0.23)$ & low $(-)$ \\
\hline${ }^{1}$ Senecio eremophilus & desert groundsel & herbaceous & composites & 0.35 & $0.37(0,1)$ & low $(+/-)$ \\
\hline${ }^{1}$ Senecio wootonii & Wooton's ragwort & herbaceous & composites & 0.02 & $0.18(0.18,0.18)$ & low \\
\hline Solidago spp. & goldenrod & herbaceous & composites & 0.05 & $0.16(0,0.41)$ & low $(-)$ \\
\hline Solidago mollis & velvety goldenrod & herbaceous & composites & 0.07 & $0.13(0.01,0.26)$ & low \\
\hline Taraxacum officinale & common dandelion & herbaceous & composites & 0.30 & $0.26(0,1)$ & low $(-)$ \\
\hline Tragopogon dubius & yellow salsify & herbaceous & composites & 0.02 & $0(0,0)$ & low \\
\hline Pteridium aquilinum & western brackenfern & herbaceous & ferns & 0.05 & $0.38(0.04,0.96)$ & low $(-)$ \\
\hline Blepharoneuron tricholepis & pine dropseed & herbaceous & grasses & 0.14 & $0.36(0,1)$ & low $(-)$ \\
\hline Bromus anomalus & nodding brome & herbaceous & grasses & 0.02 & $0(0,0)$ & low \\
\hline Bromus carinatus & California brome & herbaceous & grasses & 0.02 & $0(0,0)$ & low $(-)$ \\
\hline Bromus catharticus & rescuegrass & herbaceous & grasses & 0.02 & $0.04(0.04,0.04)$ & low $(-)$ \\
\hline${ }^{1}$ Bromus ciliatus & fringed brome & herbaceous & grasses & 0.16 & $0.31(0,0.93)$ & low $(+)$ \\
\hline Bromus inermis & smooth brome & herbaceous & grasses & 0.19 & $0.13(0,0.72)$ & low $(+/-)$ \\
\hline Bromus tectorum & cheatgrass & herbaceous & grasses & 0.25 & $0.37(0,1)$ & low $(+/-)$ \\
\hline
\end{tabular}


Table A1. Cont.

\begin{tabular}{|c|c|c|c|c|c|c|}
\hline \multirow{2}{*}{$\begin{array}{l}\text { Scientific Name } \\
\text { Dactylis glomerata }\end{array}$} & \multirow{2}{*}{$\begin{array}{c}\text { Common Name } \\
\text { orchardgrass }\end{array}$} & \multicolumn{2}{|c|}{ Foxx and Hoard 1995 Class } & \multirow{2}{*}{$\begin{array}{c}\text { Frequency (\%) } \\
0.07\end{array}$} & \multirow{2}{*}{$\begin{array}{c}\begin{array}{c}\text { Gradient Value } \\
\text { Mean (min, max) }\end{array} \\
0.34(0,0.81)\end{array}$} & \multirow{2}{*}{$\begin{array}{c}\text { Gradient Mean Class } \\
\text { low }(-)\end{array}$} \\
\hline & & herbaceous & grasses & & & \\
\hline Elymus $\mathrm{x}$ pseudorepens & false quackgrass & herbaceous & grasses & 0.07 & $0.26(0,0.72)$ & low $(+)$ \\
\hline Festuca arizonica & Arizona fescue & herbaceous & grasses & 0.11 & $0.26(0.01,0.83)$ & low $(-)$ \\
\hline Festuca brevipila & hard fescue & herbaceous & grasses & 0.09 & $0.27(0,0.81)$ & low $(-)$ \\
\hline Festuca spp. & fescue & herbaceous & grasses & 0.02 & $0(0,0)$ & low \\
\hline Muhlenbergia wrightii & spike muhly & herbaceous & grasses & 0.04 & $0(0,0)$ & low \\
\hline Pascopyrum smithii & western wheatgrass & herbaceous & grasses & 0.18 & $0.14(0,0.97)$ & low $(+/-)$ \\
\hline${ }^{1}$ Piptatherum micranthum & littleseed ricegrass & herbaceous & grasses & 0.02 & $0.01(0.01,0.01)$ & low $(-)$ \\
\hline Poa pratensis & Kentucky bluegrass & herbaceous & grasses & 0.35 & $0.31(0,1)$ & low $(+/-)$ \\
\hline Schizachyrium scoparium & little bluestem & herbaceous & grasses & 0.05 & $0.39(0,0.95)$ & low $(-)$ \\
\hline Carex geophila & White Mountain sedge & herbaceous & rushes and sedges & 0.09 & $0.22(0,0.94)$ & low \\
\hline Carex inops ssp. heliophila & sun sedge & herbaceous & rushes and sedges & 0.23 & $0.33(0,0.96)$ & low $(+/-)$ \\
\hline Carex pellita & woolly sedge & herbaceous & rushes and sedges & 0.02 & $0(0,0)$ & low \\
\hline Carex rossii & Ross' sedge & herbaceous & rushes and sedges & 0.30 & $0.38(0,1)$ & low $(-)$ \\
\hline Juncus arcticus var. balticus & Baltic rush & herbaceous & rushes and sedges & 0.02 & $0(0,0)$ & low \\
\hline Androsace septentrionalis & pygmyflower rockjasmine & herbaceous & showy dicots & 0.11 & $0.2(0.01,0.81)$ & low $(-)$ \\
\hline Apocynum androsaemifolium & spreading dogbane & herbaceous & showy dicots & 0.04 & $0.21(0,0.41)$ & low $(-)$ \\
\hline Capsella bursa-pastoris & Shepard's purse & herbaceous & showy dicots & 0.02 & $0.01(0.01,0.01)$ & low \\
\hline Cerastium arvense & mouseear chickweed & herbaceous & showy dicots & 0.19 & $0.37(0,1)$ & low $(-)$ \\
\hline Corydalis aurea & golden smoke & herbaceous & showy dicots & 0.14 & $0.05(0,0.18)$ & low $(-)$ \\
\hline Cryptantha cinerea & James' catseye & herbaceous & showy dicots & 0.05 & $0.18(0.02,0.35)$ & low $(-)$ \\
\hline Dasiphora fruticosa ssp. floribunda & shrubby cinquefoil & herbaceous & shrubs & 0.02 & $0(0,0)$ & low \\
\hline Descurainia spp. & tansymustard & herbaceous & showy dicots & 0.04 & $0(0,0.01)$ & low $(-)$ \\
\hline Erigeron speciosus & aspen fleabane & herbaceous & composites & 0.05 & $0.03(0,0.08)$ & low $(-)$ \\
\hline${ }^{1}$ Fragaria spp. & strawberry & herbaceous & showy dicots & 0.04 & $0.13(0.08,0.18)$ & low \\
\hline${ }^{1}$ Fragaria virginiana & Virginia strawberry & herbaceous & showy dicots & 0.05 & $0.28(0,0.81)$ & low \\
\hline Geranium caespitosum & pineywoods geranium & herbaceous & showy dicots & 0.07 & $0.03(0.01,0.05)$ & low $(-)$ \\
\hline Geranium richardsonii & Richardson's geranium & herbaceous & showy dicots & 0.09 & $0.34(0,0.96)$ & low $(+)$ \\
\hline Glandularia bipinnatifida & Dakota mock vervain & herbaceous & showy dicots & 0.02 & $0.05(0.05,0.05)$ & low \\
\hline Hackelia floribunda & manyflowered stickseed & herbaceous & showy dicots & 0.04 & $0.04(0.02,0.05)$ & low \\
\hline Heuchera parvifolia & littleleaf alumroot & herbaceous & showy dicots & 0.02 & $0.05(0.05,0.05)$ & low \\
\hline Lathyrus spp. & peavine & herbaceous & showy dicots & 0.02 & $0.08(0.08,0.08)$ & low \\
\hline Lithospermum multiflorum & manyflowered gromwell & herbaceous & showy dicots & 0.21 & $0.33(0,1)$ & low $(+/-)$ \\
\hline Mentzelia multiflora & manyflowered mentzelia & herbaceous & showy dicots & 0.02 & $0(0,0)$ & low \\
\hline Oenothera elata ssp. hirsutissima & Hooker's eveningprimrose & herbaceous & showy dicots & 0.04 & $0(0,0.01)$ & low $(-)$ \\
\hline
\end{tabular}


Table A1. Cont.

\begin{tabular}{|c|c|c|c|c|c|c|}
\hline \multirow{2}{*}{$\begin{array}{c}\text { Scientific Name } \\
{ }^{1} \text { Penstemon barbatus }\end{array}$} & \multirow{2}{*}{$\begin{array}{c}\text { Common Name } \\
\text { beardlip penstemon }\end{array}$} & \multicolumn{2}{|c|}{ Foxx and Hoard 1995 Class } & \multirow{2}{*}{$\begin{array}{c}\text { Frequency (\%) } \\
0.19\end{array}$} & \multirow{2}{*}{$\begin{array}{c}\begin{array}{c}\text { Gradient Value } \\
\text { Mean (min, max) }\end{array} \\
0.38(0,1)\end{array}$} & \multirow{2}{*}{$\begin{array}{c}\text { Gradient Mean Class } \\
\text { low }(+/-)\end{array}$} \\
\hline & & herbaceous & showy dicots & & & \\
\hline Thalictrum fendleri & Fendler's meadowrue & herbaceous & showy dicots & 0.14 & $0.3(0,0.96)$ & low $(-)$ \\
\hline Trifolium repens & white clover & herbaceous & showy dicots & 0.07 & $0.27(0,1)$ & low $(+)$ \\
\hline Verbascum thapsus & common mullein & herbaceous & showy dicots & 0.35 & $0.21(0,0.99)$ & low $(+/-)$ \\
\hline Vicia americana & American vetch & herbaceous & showy dicots & 0.18 & $0.39(0,1)$ & low $(+/-)$ \\
\hline${ }^{1}$ Maianthemum stellatum & starry false Solomon's seal & herbaceous & showy monocots & 0.05 & $0.29(0,0.81)$ & low \\
\hline Chenopodium fremontii & Fremont's goosefoot & herbaceous & herbaceous dicots & 0.28 & $0.2(0,0.97)$ & low $(+/-)$ \\
\hline Chenopodium spp. & goosefoot & herbaceous & herbaceous dicots & 0.07 & $0.23(0,0.81)$ & low \\
\hline Ceanothus fendleri & Fendler's ceanothus & woody & shrubs & 0.16 & $0.39(0.01,1)$ & low $(+/-)$ \\
\hline${ }^{1}$ Juniperus communis & common juniper & woody & shrubs & 0.02 & $0(0,0)$ & low \\
\hline${ }^{1}$ Mahonia repens & creeping barberry & woody & shrubs & 0.02 & $0.01(0.01,0.01)$ & low \\
\hline Physocarpus monogynus & mountain ninebark & woody & shrubs & 0.02 & $0.01(0.01,0.01)$ & low $(-)$ \\
\hline Prunus virginiana & common chokecherry & woody & shrubs & 0.05 & $0.02(0,0.05)$ & low \\
\hline Quercus gambelii & Gambel's oak & woody & shrubs & 0.49 & $0.36(0,1)$ & low $(+/-)$ \\
\hline Ribes spp. & currant; gooseberry & woody & shrubs & 0.02 & $0.16(0.16,0.16)$ & low $(-)$ \\
\hline Ribes leptanthum & trumpet gooseberry & woody & shrubs & 0.05 & $0.35(0,1)$ & low $(+)$ \\
\hline Robinia neomexicana & New Mexico locust & woody & shrubs & 0.63 & $0.3(0,1)$ & low $(+/-)$ \\
\hline Rosa woodsii & Woods' rose & woody & shrubs & 0.25 & $0.36(0,1)$ & low $(+/-)$ \\
\hline Rubus idaeus & Red Raspberry & woody & shrubs & 0.11 & $0.33(0,1)$ & low $(+/-)$ \\
\hline${ }^{1}$ Rubus parviflorus & thimbleberry & woody & shrubs & 0.04 & $0.05(0.04,0.05)$ & low \\
\hline Acer glabrum & Rocky Mountain maple & woody & trees & 0.02 & $0.05(0.05,0.05)$ & low \\
\hline Cornus sericea & redosier dogwood & woody & trees & 0.02 & $0.05(0.05,0.05)$ & low \\
\hline${ }^{1}$ Clematis columbiana & rock clematis & woody & vines and trailing plants & 0.12 & $0.15(0,0.55)$ & low $(-)$ \\
\hline Clematis spp. & clematis & woody & vines and trailing plants & 0.07 & $0.23(0.01,0.81)$ & low $(-)$ \\
\hline
\end{tabular}

${ }^{1}$ Species included in 'forest understory' category; Figure $4 .{ }^{*}$ Hymenoxys acaulis synonym: Tetraneuris acaulis; ** Chenopodium graveolens synonym: Dysphania graveolens. 


\section{References}

1. Turner, M.G.; Hargrove, W.W.; Gardner, R.H.; Romme, W.H. Effects of fire on landscape heterogeneity in Yellowstone National Park, Wyoming. J. Veg. Sci. 1994, 5, 731-742. [CrossRef]

2. Burton, P.J.; Parisien, M.-A.; Hicke, J.A.; Hall, R.J.; Freeburn, J.T. Large fires as agents of ecological diversity in the North American boreal forest. Int. J. Wildl. Fire 2008, 17, 754-767. [CrossRef]

3. Turner, M.G. Disturbance and landscape dynamics in a changing world. Ecology 2010, 91, $2833-2849$. [CrossRef] [PubMed]

4. Leonard, S.W.J.; Bennett, A.F.; Clarke, M.F. Determinants of the occurrence of unburnt forest patches: Potential biotic refuges within a large, intense wildfire in south-eastern Australia. For. Ecol. Manag. 2014, 314, 85-93. [CrossRef]

5. Robinson, N.M.; Leonard, S.W.J.; Bennett, A.F.; Clarke, M.F. Refuges for birds in fire-prone landscapes: The influence of fire severity and fire history on the distribution of forest birds. For. Ecol. Manag. 2014, 318, 110-121. [CrossRef]

6. Reside, A.E.; Welbergen, J.A.; Phillips, B.L.; Wardell-Johnson, G.W.; Keppel, G.; Ferrier, S.; Williams, S.E.; van der Wal, J. Characteristics of climate change refugia for Australian biodiversity. Austral Ecol. 2014, 39, 887-897. [CrossRef]

7. Keppel, G.; Mokany, K.; Wardell-Johnson, G.W.; Phillips, B.L.; Welbergen, J.A.; Reside, A.E. The capacity of refugia for conservation planning under climate change. Front. Ecol. Environ. 2015, 13, 106-112. [CrossRef]

8. Keppel, G.; van Niel, K.P.; Wardell-Johnson, G.W.; Yates, C.J.; Byrne, M.; Mucina, L.; Schut, A.G.T.; Hopper, S.D.; Franklin, S.E. Refugia: Identifying and understanding safe havens for biodiversity under climate change. Glob. Ecol. Biogeogr. 2012, 21, 393-404. [CrossRef]

9. Camp, A.; Oliver, C.; Hessburg, P.; Everett, R. Predicting late-successional fire refugia pre-dating European settlement in the Wenatchee mountains. For. Ecol. Manag. 1997, 95, 63-77. [CrossRef]

10. Mackey, B.; Lindenmayer, D.B.; Gill, A.M.; McCarthy, M.A.; Lindesay, J. Wildlife, Fire and Future Climate: A Forest Ecosystem Analysis; CSIRO Publishing: Collingwood, Australia, 2002.

11. Krawchuk, M.A.; Haire, S.L.; Coop, J.D.; Parisien, M.-A.; Whitman, E.; Chong, G.W.; Miller, C. Topographic and fire weather controls of fire refugia in forested ecosystems of northwestern North America. Ecosphere 2016, 7, e01632. [CrossRef]

12. Wilkin, K.; Ackerly, D.; Stephens, S. Climate change refugia, fire ecology and management. Forests 2016. [CrossRef]

13. Ouarmim, S.; Asselin, H.; Hély, C.; Bergeron, Y.; Ali, A.A. Long-term dynamics of fire refuges in boreal mixedwood forests. J. Quat. Sci. 2014, 29, 123-129. [CrossRef]

14. Madoui, A.; Leduc, A.; Gauthier, S.; Bergeron, Y. Spatial pattern analyses of post-fire residual stands in the black spruce boreal forest of western Quebec. Int. J. Wildl. Fire 2010, 19, 1110. [CrossRef]

15. Collins, L.; Bradstock, R.A.; Tasker, E.M.; Whelan, R.J. Can gullies preserve complex forest structure in frequently burnt landscapes? Biol. Conserv. 2012, 153, 177-186. [CrossRef]

16. Román-Cuesta, R.M.; Gracia, M.; Retana, J. Factors influencing the formation of unburned forest islands within the perimeter of a large forest fire. For. Ecol. Manag. 2009, 258, 71-80. [CrossRef]

17. Buma, B. Disturbance interactions: Characterization, prediction, and the potential for cascading effects. Ecosphere 2015, 6, art70. [CrossRef]

18. Coop, J.D.; Parks, S.A.; McClernan, S.R.; Holsinger, L.M. Influences of prior wildfires on vegetation response to subsequent fire in a reburned southwestern landscape. Ecol. Appl. 2016, 26, 346-354. [CrossRef] [PubMed]

19. Donato, D.C.; Fontaine, J.B.; Campbell, J.L.; Robinson, W.D.; Kauffman, J.B.; Law, B.E. Post-wildfire logging hinders regeneration and increases fire risk. Science 2006, 311, 352. [CrossRef] [PubMed]

20. Haire, S.L.; McGarigal, K. Inhabitants of landscape scars: Succession of woody plants after large, severe forest fires in Arizona and New Mexico. Southwest. Nat. 2008, 53, 146-161. [CrossRef]

21. Serra-Diaz, J.M.; Scheller, R.M.; Syphard, A.D.; Franklin, J. Disturbance and climate microrefugia mediate tree range shifts during climate change. Landsc. Ecol. 2015, 30, 1039-1053. [CrossRef]

22. Ouarmim, S.; Asselin, H.; Bergeron, Y.; Ali, A.A.; Hély, C. Stand structure in fire refuges of the eastern Canadian boreal mixedwood forest. For. Ecol. Manag. 2014, 324, 1-7. [CrossRef] 
23. Anand, M.; Leithead, M.; Silva, L.C.R.; Wagner, C.; Ashiq, M.W.; Cecile, J.; Drobyshev, I.; Bergeron, Y.; Das, A.; Bulger, C. The scientific value of the largest remaining old-growth red pine forests in North America. Biodivers. Conserv. 2013, 22, 1847-1861. [CrossRef]

24. Bond, W.J.; Dickinson, K.J.M.; Mark, A.F. What limits the spread of fire-dependent vegetation? Evidence from geographic variation of serotiny in a New Zealand shrub. Glob. Ecol. Biogeogr. 2004, 13, 115-127. [CrossRef]

25. Mackey, B.; Berry, S.; Hugh, S.; Ferrier, S.; Harwood, T.D.; Williams, K.J. Ecosystem greenspots: Identifying potential drought, fire, and climate-change micro-refuges. Ecol. Appl. 2012, 22, 1852-1864. [CrossRef] [PubMed]

26. Clarke, P.J. Habitat islands in fire-prone vegetation: Do landscape features influence community composition? J. Biogeogr. 2002, 29, 677-684. [CrossRef]

27. Gould, S.F.; Hugh, S.; Porfirio, L.L.; Mackey, B. Ecosystem greenspots pass the first test. Landsc. Ecol. 2015, 30, 141-151. [CrossRef]

28. Wood, S.W.; Murphy, B.P.; Bowman, D.M.J.S. Firescape ecology: How topography determines the contrasting distribution of fire and rain forest in the south-west of the Tasmanian Wilderness World Heritage Area. J. Biogeogr. 2011, 38, 1807-1820. [CrossRef]

29. Kolden, C.A.; Abatzoglou, J.T.; Lutz, J.A.; Cansler, C.A.; Kane, J.T.; van Wagtendonk, J.W.; Key, C.H. Climate contributors to forest mosaics: Ecological persistence following wildfire. Northwest Sci. 2015, 89, 219-238. [CrossRef]

30. Kolden, C.A.; Lutz, J.A.; Key, C.H. Mapped versus actual burned area within wildfire perimeters: Characterizing the unburned. For. Ecol. 2012, 286, 38-47. [CrossRef]

31. Nelson, T.A.; Boots, B. Detecting spatial hot spots in landscape ecology. Ecography (Cop.) 2008, 31, 556-566. [CrossRef]

32. Silverman, B.W. Density Estimation for Statistics and Data Analysis; Chapman and Hall: New York, NY, USA, 1986.

33. Azzalini, A.; Torelli, N. Clustering via nonparametric density estimation. Stat. Comput. 2007, 17, 71-80. [CrossRef]

34. Longland, W.S.; Bateman, S.L. Viewpoint: The ecological value of shrub islands on disturbed sagebrush rangelands. J. Range Manag. 2014, 55, 571-575. [CrossRef]

35. Liebmann, M.J.; Farella, J.; Roos, C.I.; Stack, A.; Martini, S.; Swetnam, T.W. Native American depopulation, reforestation, and fire regimes in the Southwest United States, 1492-1900 CE. Proc. Natl. Acad. Sci. USA 2016, 113, 696-704. [CrossRef] [PubMed]

36. Allen, C.D. Lots of Lightning and Plenty of People: An Ecological History of Fire in the Upland Southwest. In Fire, Native Peoples, and the Natural Landscape; Vale, T.R., Ed.; Island Press: Washington, DC, USA, 2002; pp. 143-193.

37. Dumire, W.W.; Tierney, G.D. Wild plants of the Pueblo Province: Exploring Ancient and Enduring Uses; Museum of New Mexico Press: Santa Fe, NM, USA, 1995.

38. Swetnam, T.W.; Farella, J.; Roos, C.I.; Liebmann, M.J.; Falk, D.A.; Allen, C.D. Multiscale perspectives of fire, climate and humans in western North America and the Jemez Mountains, USA. Philos. Trans. R. Soc. Lond. B Biol. Sci. 2016. [CrossRef] [PubMed]

39. Muldavin, E.; Kennedy, A.; Jackson, C.; Neville, P.; Neville, T.; Schultz, K.; Reid, M. Vegetation Classification and Map: Bandelier National Monument Natural Resource 361 Technical Report NPS/SCPN/NRTR-2011/438; National Park Service: Fort Collins, CO, USA, 2011.

40. Commission for Environmental Cooperation. North American Terrestrial Ecosystems—Level III; Commission for Environmental Cooperation: Montréal, QC, Canada, 2011.

41. Swetnam, T.W.; Betancourt, J.L.; Swetnam, T.W.; Betancourt, J.L. Mesoscale disturbance and ecological response to decadal climatic variability in the American Southwest. J. Clim. 1998, 11, 3128-3147. [CrossRef]

42. Wolter, K. Multivariate ENSO Index. Available online: http://www.esrl.noaa.gov/psd/enso/mei/ (accessed on 14 November 2016).

43. Schoeffler, F.J.; Wachter, J.B. Dynamic Fire Weather Associated with the June 2011 New Mexico (USA) Las Conchas Fire (95th American Meteorological Society Annual Meeting). In Proceedings of the 95th American Meterorological Society, Phoenix, AZ, USA, 4-8 January 2015. 
44. Reneau, S.L.; Mcdonald, E.V. Landscape History and Processes on the Pajarito Plateau, Northern New Mexico; Los Alamos National Laboratory: Los Alamos, NM, USA, 1996.

45. Schoennagel, T.; Veblen, T.T.; Romme, W.H. The interaction of fire, fuels, and climate across Rocky Mountain forests. Bioscience 2004, 54, 661-676. [CrossRef]

46. Romme, W.H.; Allen, C.D.; Bailey, J.D.; Baker, W.L.; Bestelmeyer, B.T.; Brown, P.M.; Eisenhart, K.S.; Floyd, M.L.; Huffman, D.W.; Jacobs, B.F.; et al. Historical and modern disturbance regimes, stand structures, and landscape dynamics in piñon-juniper vegetation of the Western United States. Rangel. Ecol. Manag. 2009, 62, 203-222. [CrossRef]

47. Haire, S.L.; McGarigal, K. Effects of landscape patterns of fire severity on regenerating ponderosa pine forests (Pinus ponderosa) in New Mexico and Arizona, USA. Landsc. Ecol. 2010, 25, 1055-1069. [CrossRef]

48. Eidenshink, J.; Schwind, B.; Brewer, K.; Zhu, Z.; Quayle, B.; Howard, S.; Falls, S.; Falls, S. A project for monitoring trends in burn severity. Fire Ecol. 2007, 3, 3-21. [CrossRef]

49. GEOMAC. Geosciences and Environmental Change Science Center (GECSC) Outgoing Datasets. Available online: http://rmgsc.cr.usgs.gov/outgoing/GeoMAC/2011_fire_data/New_Mexico/Las_ Conchas/ (accessed on 14 November 2016).

50. R Core Team. R: A Language and Environment for Statistical Computing; R Core Team: Vienna, Austria, 2016.

51. Wang, T.; Hamann, A.; Spittlehouse, D.; Carroll, C. Locally downscaled and spatially customizable climate data for historical and future periods for North America. PLoS ONE 2016, 11, 1-17. [CrossRef] [PubMed]

52. Hijmans, R.J. Raster: Geographic Data Analysis and Modeling. R Package Version 2.5-8. Available online: https:/ / cran.r-project.org/ package=raster (accessed on 14 November 2016).

53. Brenning, A. Statistical Geocomputing Combining R and SAGA: The example of landslide susceptibility analysis with Generalized Additive Models. In SAGA-Seconds Out (Hamburger Beiträge zur Physischen Geographie und Landschaftsökologie; Böhner, J., Blaschke, T., Montanarella, L., Eds.; Saga Press: Portland, OR, USA, 2008; Volume 19, pp. 23-32.

54. Brenning, A.; Bangs, D. RSAGA: SAGA Geoprocessing and Terrain Analysis in R. Available online: https:/ /CRAN.R-project.org/package=RSAGA (accessed on 14 November 2016).

55. Wood, S.N. mgcv: Mixed GAM Computation Vehicle with GCV/AIC/REML Smoothness Estimation. R Package Version 1.8-15. Available online: https://cran.r-project.org/package $=$ mgcv (accessed on 14 November 2016).

56. Wood, S.N. Fast stable restricted maximum likelihood and marginal likelihood estimation of semiparametric generalized linear models. J. R. Stat. Soc. 2011, 73, 3-36. [CrossRef]

57. Hurvich, C.M.; Tsai, C.-L. Model selection for least absolute deviations regression in small samples. Stat. Probab. Lett. 1990, 9, 259-265. [CrossRef]

58. Oksanen, J.; Blanchet, F.G.; Friendly, M.; Kindt, R.; Legendre, P.; McGlinn, D.; Minchin, P.R.; O’Hara, R.B.; Simpson, G.L.; Solymos, P.; et al. Vegan: Community Ecology Package. Available online: https://cran.rproject.org/package=vegan (accessed on 14 November 2016).

59. Foxx, T.S.; Hoard, D. Flowering Plants of the Southwestern Woodlands; Otowi Crossing Press: Los Alamos, NM, USA, 1995.

60. Turner, M.G.; Romme, W.H.; Gardner, R.H.; Hargrove, W.W. Effects of fire size and pattern on early succession in Yellowstone National Park. Ecol. Monogr. 1997, 67, 411-433. [CrossRef]

61. Turner, M.G.; Romme, W.H.; Tinker, D.B. Surprises and lessons from the 1988 Yellowstone fires. Front. Ecol. Environ. 2003, 1, 351-358. [CrossRef]

62. Coop, J.D.; Givnish, T.J. Gradient analysis of reversed treelines and grasslands of the Valles Caldera, New Mexico. J. Veg. Sci. 2007, 18, 43-54. [CrossRef]

63. Holden, Z.A.; Morgan, P.; Evans, J.S. A predictive model of burn severity based on 20-year satellite-inferred burn severity data in a large southwestern US wilderness area. For. Ecol. Manag. 2009, 258, 2399-2406. [CrossRef]

64. Kane, V.R.; Lutz, J.A.; Cansler, C.A.; Povak, N.A.; Churchill, D.J.; Smith, D.F.; Kane, J.T.; North, M.P. Water balance and topography predict fire and forest structure patterns. For. Ecol. Manag. 2015, 338, 1-13. [CrossRef]

65. Dobrowski, S.Z. A climatic basis for microrefugia: The influence of terrain on climate. Glob. Chang. Biol. 2010, 17, 1022-1035. [CrossRef] 
66. Hume, A.; Chen, H.Y.H.; Taylor, A.R.; Kayahara, G.J.; Man, R. Soil C:N:P dynamics during secondary succession following fire in the boreal forest of central Canada. For. Ecol. Manag. 2016, 369, 1-9. [CrossRef]

67. Herrmann, J.D.; Carlo, T.A.; Brudvig, L.A.; Damschen, E.I.; Haddad, N.M.; Levey, D.J.; Orrock, J.L.; Tewksbury, J.J. Connectivity from a different perspective: Comparing seed dispersal kernels in connected vs. unfragmented landscapes. Ecology 2016, 97, 1274-1282. [CrossRef] [PubMed]

68. Neary, D.G.; Ryan, K.C.; de Bano, L.F. Wildland Fire in Ecosystems: Effects of Fire on Soils and Water; Gen. Tech. Rep. RMRS-GTR-42-vol.4; US Department of Agriculture, Forest Service, Rocky Mountain Research Station: Ogden, UT, USA, 2005.

69. Weber, C.F.; Lockhart, J.S.; Charaska, E.; Aho, K.; Lohse, K.A. Bacterial composition of soils in ponderosa pine and mixed conifer forests exposed to different wildfire burn severity. Soil Biol. Biochem. 2014, 69, 242-250. [CrossRef]

70. Kotliar, N.B.; Kennedy, P.L.; Ferree, K. Avifaunal responses to fire in southwestern montane forests along a burn severity gradient. Ecol. Appl. 2007, 17, 491-507. [CrossRef] [PubMed]

71. Lorenz, T.J.; Vierling, K.T.; Kozma, J.M.; Millard, J.E.; Raphael, M.G. Space use by white-headed woodpeckers and selection for recent forest disturbances. J. Wildl. Manag. 2015, 79, 1286-1297. [CrossRef]

72. Chia, E.K.; Bassett, M.; Nimmo, D.G.; Leonard, S.W.J.; Ritchie, E.G.; Clarke, M.F.; Bennett, A.F. Fire severity and fire-induced landscape heterogeneity affect arboreal mammals in fire-prone forests. Ecosphere 2015, 6, art190. [CrossRef]

73. Savage, M.; Mast, J.N.; Feddema, J.J. Double whammy: High-severity fire and drought in ponderosa pine forests of the Southwest. Can. J. For. Res. 2013, 43, 570-583. [CrossRef]

74. Savage, M.; Mast, J.N. How resilient are southwestern ponderosa pine forests after crown fires? Can. J. For. Res. 2005, 35, 967-977. [CrossRef]

75. Swanson, M.E.; Franklin, J.F.; Beschta, R.L.; Crisafulli, C.M.; Della Sala, D.A.; Hutto, R.L.; Lindenmayer, D.B.; Swanson, F.J. The forgotten stage of forest succession: Early-successional ecosystems on forest sites. Front. Ecol. Environ. 2011, 9, 117-125.

76. Roberts, S.L.; Kelt, D.A.; van Wagtendonk, J.W.; Miles, A.K.; Meyer, M.D. Effects of fire on small mammal communities in frequent-fire forests in California. J. Mammal. 2015, 96, 107-119. [CrossRef]

77. Soulard, C.E.; Albano, C.M.; Villarreal, M.L.; Walker, J.J. Continuous 1985-2012 Landsat monitoring to assess fire effects on meadows in Yosemite National Park, California. Remote Sens. 2016, 8, 371. [CrossRef]

78. Debinski, D.M.; Jakubauskas, M.E.; Kindscher, K. Montane meadows as indicators of environmental change. Environ. Monit. Assess. 2000, 64, 213-225. [CrossRef]

79. Schwilk, D.W.; Keeley, J.E. A plant distribution shift: Temperature, drought or past disturbance? PLoS ONE 2012, 7, e31173. [CrossRef] [PubMed]

80. Hampe, A.; Petit, R.J. Conserving biodiversity under climate change: The rear edge matters. Ecol. Lett. 2005, 8, 461-467. [CrossRef] [PubMed]

81. Thompson, M.P.; Freeborn, P.; Rieck, J.D.; Calkin, D.E.; Gilbertson-Day, J.W.; Cochrane, M.A.; Hand, M.S. Quantifying the influence of previously burned areas on suppression effectiveness and avoided exposure: A case study of the Las Conchas Fire. Int. J. Wildl. Fire 2016, 25, 167. [CrossRef]

82. Stewart, J.R.; Lister, A.M.; Barnes, I.; Dalén, L. Refugia revisited: Individualistic responses of species in space and time. Proc. Biol. Sci. 2010, 277, 661-671. [CrossRef] [PubMed]

83. Allen, C.D.; Breshears, D.D. Drought-induced shift of a forest woodland ecotone: Rapid landscape response to climate variation. Proc. Natl. Acad. Sci. USA 1998, 95, 14839-14842. [CrossRef] [PubMed]

84. Hampe, A.; Jump, A.S. Climate relicts: Past, present, and future. Annu. Rev. Ecol. Evol. Syst. 2011, 42, 313-333. [CrossRef]

85. Lindenmayer, D.B.; Macgregor, C.; Wood, J.T.; Cunningham, R.B.; Crane, M.; Michael, D.; Montague-Drake, R.; Brown, D.; Fortescue, M.; Dexter, N.; et al. What factors influence rapid post-fire site re-occupancy? A case study of the endangered Eastern Bristlebird in eastern Australia. Int. J. Wildl. Fire 2009, 18, 84-95. [CrossRef]

86. Berry, L.E.; Driscoll, D.A.; Stein, J.A.; Blanchard, W.; Banks, S.C.; Bradstock, R.A.; Lindenmayer, D.B. Identifying the location of fire refuges in wet forest ecosystems. Ecol. Appl. 2015, 25, 2337-2348. [CrossRef] [PubMed]

87. Stephens, S.L.; Agee, J.K.; Fule, P.Z.; North, M.P.; Romme, W.H.; Swetnam, T.W.; Turner, M.G. Managing forests and fire in changing climates. Science 2013, 342, 41-42. [CrossRef] [PubMed] 
88. Cortés-Montaño, C.; Fulé, P.Z.; Falk, D.A.; Villanueva-Díaz, J.; Yocom, L.L. Linking old-growth forest composition, structure, fire history, climate and land-use in the mountains of northern México. Ecosphere 2012, 3, art106. [CrossRef]

89. Margolis, E.Q.; Malevich, S.B. Historical dominance of low-severity fire in dry and wet mixed-conifer forest habitats of the endangered terrestrial Jemez Mountains salamander (Plethodon neomexicanus). For. Ecol. Manag. 2016, 375, 12-26. [CrossRef]

90. Shinneman, D.J.; Means, R.E.; Potter, K.M.; Hipkins, V.D. Exploring climate niches of ponderosa pine (Pinus ponderosa Douglas ex Lawson) haplotypes in the western United States: Implications for evolutionary history and conservation. PLoS ONE 2016, 11, e0151811. [CrossRef] [PubMed]

(C) 2017 by the authors. Licensee MDPI, Basel, Switzerland. This article is an open access article distributed under the terms and conditions of the Creative Commons Attribution (CC BY) license (http:/ / creativecommons.org/licenses/by/4.0/). 